Article

\title{
Financial Analysis of International Energy Trade: A Strategic Outlook for EU-15
}

\author{
Serhat Yüksel *(D), Hasan Dinçer@i) and Yurdagül Meral \\ School of Business, İstanbul Medipol University, Kavacık Mah. Ekinciler Cad. No.19 Kavacık Kavşağ1—Beykoz, \\ 34810 İstanbul, Turkey; hdincer@medipol.edu.tr (H.D.); ymeral@medipol.edu.tr (Y.M.) \\ * Correspondence: serhatyuksel@medipol.edu.tr; Tel.: +90-216-681-5000
}

Received: 30 December 2018; Accepted: 27 January 2019; Published: 29 January 2019

\begin{abstract}
This study aims to analyse the international energy trade in EU-15. Within this context, 6 items of international transport and energy trade have been selected to evaluate the performance of European Union (EU) 15 countries. For this purpose, a comparative analysis has been applied by including and excluding the data of energy trade in international transport for the years between 2013 and 2016. In this framework, interval type-2 fuzzy decision-making trial and evaluation laboratory (DEMATEL) and technique for order preference by similarity to ideal solution (TOPSIS) approaches are considered. The findings show that road and sea have the highest importance for international transport and energy trade. However, pipeline and electricity, which represent the energy trade, take place on the last ranks. Another important conclusion is that there is almost no difference in the ranking of international transport performance including and excluding energy trade. While considering these issues, it is recommended that that European countries should take some actions to increase the energy production. The main reason is that it has a positive influence on both international trade volume and industrial production. Thus, they can focus on renewable energy production which leads to lower cost in this process.
\end{abstract}

Keywords: energy; European Union; service trade; interval type-2 DEMATEL; TOPSIS

\section{Introduction}

The European Union (EU) is one of the top traders of international trade. As per the statistics of World Trade Organization in 2018, total exports of the world are US\$ 17.43 trillion as of 2017. The top three traders are China, US and Germany as of 2017 with their total value of trade US\$ 5,300 billion. The European Union was the largest exporter of manufactured goods in 2017, with a value of US\$ 4.67 trillion, followed by China with US\$ 2.13 trillion and the United States with US\$ 1.13 trillion. The European Union is the largest union, regional trade agreement with its 34 percent of global trade. EU actually succeeded their establishment goal by accounting for a third of world exports of goods in 2017. Total volume of service trade is US\$ 5.19 trillion in 2017 with 7 percent increase from 2016. United States with US\$ 761.7 billion in service exports and US\$ 516.0 billion in service imports is ranked as number one in the list, followed by United Kingdom and Germany. The statistics of the European Union for International Trade in services show that, although nowadays Brexit is in process, United Kingdom's value of exports services is the highest with 301 billion Euro. Germany is the highest in value of imports services with 277 billion Euro in 2016.

Additionally, with respect to the energy market, the European Union is also one of the most important markets in the world. The EU energy market, which is over 500 million users, is the world's largest regional energy domestic market and the largest energy importer. One in three of the Europeans suffer from air pollution because majority of the European cities' population are subject to air pollution, which is accepted as damaging to health by World Health Organization [1]. Therefore, not only because 
the European Union is dependent on other countries as a major importer of energy, renewable energy is important for health purposes as well. European environment agency report indicates that 23 of 28 European countries are under required air quality standards. Air pollution harmful effect causes on human health like premature deaths in EU [2].

It is expected that natural gas demand in Europe will increase by $70-80 \%$ in 2030 compared to today. The long-term objective of the EU is to reduce greenhouse gas emissions by $80-95$ percent from the year of 1990s levels until 2050, while maintaining supply security and competitiveness as per electricity and natural gas legislation [3]. European Energy Union's common energy policy can be summarized as energy efficiency, renewable energy and nuclear energy as follows. Due to the fact that the share of buildings in total energy consumption constitutes a very significant proportion of $40 \%$, the EU imposes special rules on energy efficiency in buildings. Accordingly, taking into account local conditions, climatic conditions and cost-effectiveness of indoor and outdoor areas, measures are taken to increase the energy performance of buildings [4].

Renewable energy in EU, the development of renewable energy resources (EEC) is considered as a key priority, both in terms of supply security and the importance of combating climate change $[5,6]$. At the same time, the development of the industry for these technologies is important with Europe opening up new business in the current economic conditions. Therefore, the EU has established a renewable energy policy [3]. Nuclear energy, ensuring nuclear security in all stages of nuclear power generation and fuel cycle, radioactive wastes, decommissioning of nuclear power plants (responsibilities for decommissioning, waste management policies, radiation protection, environmental impact assessment, public awareness, disarming technical approaches and financial and economic issues [3].

The aim of the study is to evaluate the performance of European countries regarding energy trade. In the first phase of this process, 6 items of international transport and energy trade have been selected to evaluate the performance of EU 15 countries which are sea, air, rail, road, pipeline and electricity. In this framework, the data of international trade centre (ITC) Trade Map is taken into the consideration. On the other side, in the analysis process, a comparative analysis has been applied by including and excluding the data of energy trade in the international transport for the years between 2013 and 2016. Within this context, interval type-2 fuzzy DEMATEL and TOPSIS approaches are used.

This study has many different novelties. Firstly, a dynamic analysis is performed in order to see the performance of energy trade. In addition, European countries are firstly considered with respect to the energy trade performance by using fuzzy multi criteria decision making models. This situation has a positive effect on the originality of the study. Furthermore, according to the results of this study, it can be possible to understand which European countries have higher performance regarding energy trade. Hence, it is believed that this study contributes to the literature.

There are five different sections in this study. This introduction section includes general information related to the subject. The second section then analyses similar studies in the literature to identify gaps. The third section gives information about the different methodologies used in the study. Furthermore, the fourth section explains the application on EU-15 countries. Additionally, in the final section, analysis results are given.

\section{Literature Review}

Recent studies in the field tend to focus on energy, mainly efficient, renewable, sustainable, green energy, ecology and environment, nuclear energy and safety systems. Some of these studies are demonstrated on Table 1. 
Table 1. Similar Studies in the Literature.

\begin{tabular}{|c|c|c|}
\hline Author & Subject & Results \\
\hline D'Adamo and Rosa [7] & $\begin{array}{l}\text { Evaluation of the renewable } \\
\text { energy sources }\end{array}$ & $\begin{array}{l}\text { They proposed a framework to help decision makers } \\
\text { of energy policy makers. }\end{array}$ \\
\hline Magazzino [8] & $\begin{array}{l}\text { The stationary properties of per capita } \\
\text { energy use }\end{array}$ & $\begin{array}{l}\text { The findings show mixed results regarding the panel } \\
\text { stationarity of energy use per capita }\end{array}$ \\
\hline Casals et al. [9] & Electric vehicle use & $\begin{array}{l}\text { France and Norway are more successful regarding } \\
\text { electric vehicle use }\end{array}$ \\
\hline Pacesila et al. [10] & Renewable energy in Europe & $\begin{array}{l}\text { The main characteristics of the renewable energy } \\
\text { policy in Europe are underlined. }\end{array}$ \\
\hline Khanam et al. [11] & European energy policy & $\begin{array}{l}\text { The findings showed that } 49 \% \text { of the experts } \\
\text { perceived that renewable energy target would not } \\
\text { be achieved }\end{array}$ \\
\hline Magazzino [12] & $\begin{array}{l}\text { The stationary properties of per capita } \\
\text { energy use }\end{array}$ & $\begin{array}{l}\text { Most of the country series does not reject the unit } \\
\text { root null hypothesis at the } 5 \% \text { significance level }\end{array}$ \\
\hline Nicolini and Tavoni [13] & Efficiency of energy policies & $\begin{array}{l}\text { They have found that } 1 \% \text { increase in the incentive } \\
\text { tariff will increase in renewable of } 0.4-1 \%\end{array}$ \\
\hline Gökgöz and Güvercin [14] & $\begin{array}{l}\text { Energy security and renewable energy } \\
\text { efficiency in EU }\end{array}$ & $\begin{array}{l}\text { Technological development has an important effect } \\
\text { on the renewable energy efficiency. }\end{array}$ \\
\hline Dominković et al. [15] & $\begin{array}{l}\text { The future of transportation in } \\
\text { sustainable energy systems }\end{array}$ & Electric modes of transport have the highest benefits. \\
\hline Moro and Lonza [16] & Electricity carbon intensity in Europe & $\begin{array}{l}\text { Greenhouse gas (GHG) trade between countries, } \\
\text { affect the carbon intensity of electricity consumed at } \\
\text { national level. }\end{array}$ \\
\hline Carrilero et al. [17] & $\begin{array}{l}\text { Redesigning European } \\
\text { public transport }\end{array}$ & $\begin{array}{l}\text { Strengths and weaknesses are explained in order to } \\
\text { redesign public transport in Europe. }\end{array}$ \\
\hline Biresselioglu et al. [18] & Electric mobility in Europe & $\begin{array}{l}\text { Lack of charging infrastructure and economic } \\
\text { restrictions are important barriers for } \\
\text { electric mobility. }\end{array}$ \\
\hline Hasan et al. [19] & Literature review of similar studies & $\begin{array}{l}\text { Energy saving and greenhouse gas became very } \\
\text { popular topics. }\end{array}$ \\
\hline Wang et al. [20] & Literature review of similar studies & $\begin{array}{l}\text { European countries are the leader in sustainable } \\
\text { consumption and production practices. }\end{array}$ \\
\hline Liu et al. [21] & Renewable energy power systems & $\begin{array}{l}\text { They proposed a line modal potential } \\
\text { energy method. }\end{array}$ \\
\hline Amiri and Weinberger [22] & Renewable electricity & $\begin{array}{l}\text { Profitability of biofuel investment increases } \\
\text { electricity price. }\end{array}$ \\
\hline Li et al. [23] & $\begin{array}{l}\text { An integrated offshore renewable } \\
\text { energy system }\end{array}$ & $\begin{array}{l}\text { They developed a device which reduces } \\
\text { fatigue damage. }\end{array}$ \\
\hline Haratian et al. [24] & Iran's renewable energy system & Increasing the discount rates goes up the energy cost. \\
\hline Thies et al. [25] & Literature review of similar studies & $\begin{array}{l}\text { Sensitivity analysis and fuzzy logic are preferred in } \\
\text { the analysis process. }\end{array}$ \\
\hline Waltho et al. [26] & Literature review of similar studies & Supply chain network has mainly focused on carbon. \\
\hline Rahman et al. [27] & Literature review of similar studies & $\begin{array}{l}\text { Researchers prefer fuzzy logic more especially in the } \\
\text { last studies. }\end{array}$ \\
\hline Mardani et al. [28] & $\mathrm{CO}_{2}$ emissions and economic growth & $\begin{array}{l}\mathrm{CO}_{2} \text { emission should be reduced to provide } \\
\text { sustainable economic growth. }\end{array}$ \\
\hline Oh et al. [29] & Energy policies in Malaysia & $\begin{array}{l}\text { Energy efficiency contributes to the economic } \\
\text { improvement. }\end{array}$ \\
\hline Steg et al. [30] & The forces of energy consumers & $\begin{array}{l}\text { Technological development and individual behavior } \\
\text { affect energy consumption. }\end{array}$ \\
\hline Fontes and Freires [31] & Renewable energy supply chain & $\begin{array}{l}\text { Understanding of supply chain in renewable energy } \\
\text { has a great importance. }\end{array}$ \\
\hline Hatefi and Torabi [32] & $\begin{array}{l}\text { Indicators of sustainable } \\
\text { energy indices }\end{array}$ & $\begin{array}{l}\text { Life expectancy, education and GDP growth } \\
\text { positively affect sustainable energy indices }\end{array}$ \\
\hline Perlaviciute et al. [33] & Sustainable energy transition & $\begin{array}{l}\text { Sensitivity analysis and fuzzy logic are more } \\
\text { preferred in the analysis process of the latest studies. }\end{array}$ \\
\hline Segura et al. [34] & Literature review of similar studies & $\begin{array}{l}\text { PESTEL analysis became very popular in the } \\
\text { latest studies. }\end{array}$ \\
\hline
\end{tabular}


Table 1. Cont.

\begin{tabular}{|c|c|c|}
\hline Author & Subject & Results \\
\hline Gerres et al. [35] & Literature review of similar studies & $\begin{array}{l}\text { They identified the decarbonization of low } \\
\text { temperature heat by cross-sector technologies }\end{array}$ \\
\hline García-Álvarez et al. [36] & European energy regulation & $\begin{array}{l}\text { They indicated that policy makers must consider } \\
\text { importance of reducing regulatory uncertainty about } \\
\text { feed-in tariff and quota obligation policies. }\end{array}$ \\
\hline Hadjimichael [37] & EU's Blue Growth strategy & $\begin{array}{l}\text { EU's Blue Growth strategy is criticized } \\
\text { and questioned. }\end{array}$ \\
\hline Child et al. [38] & 2050 goal of renewable energy & $\begin{array}{l}\text { Their results indicate that the levelized cost of } \\
\text { electricity falls in } 2050\end{array}$ \\
\hline Tseng et al. [39] & Literature review of similar studies & $\begin{array}{l}\text { There is a sharp growth of publications about Green } \\
\text { Supply Chain Management after } 2010 .\end{array}$ \\
\hline Matschoss et al. [40] & $\begin{array}{l}\text { German regulation related to } \\
\text { renewable energy }\end{array}$ & $\begin{array}{l}\text { German regulation provides lower costs } \\
\text { of renewables. }\end{array}$ \\
\hline Bhardwaj et al. [41] & Literature review of similar studies & $\begin{array}{l}\text { Multi-criteria decision approaches (MCDA) are used } \\
\text { in energy policy decisions }\end{array}$ \\
\hline Savvidis et al. [42] & Literature review of similar studies & $\begin{array}{l}\text { They examined literature which assess the ability of } \\
\text { energy systems for major energy policies and } \\
\text { proposed a set of criteria to compare a sample of } \\
40 \text { models. }\end{array}$ \\
\hline Zappa et al. [43] & European power system in 2050 & $\begin{array}{l}100 \% \text { renewable system may not reduce year } \\
2050 \text { goal. }\end{array}$ \\
\hline Verma et al. [44] & Emerging biomass energy resource & $\begin{array}{l}\text { Black liquor is an emerging biomass energy resource } \\
\text { which ensures self-sufficient and sustainable process }\end{array}$ \\
\hline
\end{tabular}

The majority of the studies about the EU energy policy aim to help the policy makers to make a decision to choose the best alternative resource, best assessment method, forecasting their 2050 goals of EU related with environmental issues in sustainable, renewable energy. Tseng et al. [39] in their literature review of 880 papers and 236 additional papers have found that there is a sharp growth of publications about Green Supply Chain Management after 2010. Liu et al. [21], Amiri and Weinberger [22], Li et al. [23], Matschoss et al. [40] and Haratian et al. [24] also focused on this topic in their studies.

Several studies focus on assessment methods for different aspects of sustainable energy. Thies et al. [25] provided a framework for the sustainability of a product's life cycle after reviewing 142 articles on environmental management. For uncertainties with the data, decisions makers preferred to use fuzzy logic, stochastic models or sensitivity analysis. Rahman et al. [27], Oh et al. [29], Steg et al. [30], Fontes and Freires [31], Hatefi and Torabi [32] and Perlaviciute et al. [33] also emphasized the importance of this topic.

Bhardwaj et al. [41] examined the decision approaches in his review covering 167 studies related with multiple energy, development and climate objectives. Waltho et al. [26] reviewed 105 articles on green supply chain networks between 2010 and 2017. They found that supply chain network has mainly focused on carbon, four aspects as carbon policies carbon tax, carbon offset, carbon cap and carbon cap-and-trade. The four policies achieved emission reductions with a little increase in total cost.

Savvidis et al. [42] examined literature which assesses the performance of major energy policies and proposed a set of criteria to compare a sample of 40 models. Furthermore, Mardani et al. [28], in their study, claimed that recent studies have investigated $\mathrm{CO}_{2}$ emissions and economic growth in formulating energy policies, to develop sustainable energy resources and relationships between economic growth and $\mathrm{CO}_{2}$ emissions. They indicated that the $\mathrm{CO}_{2}$ emissions and economic growth relation gives policy options that have to reduce $\mathrm{CO}_{2}$ emissions by limiting factors on economic growth as well.

Additionally, some of these studies examined and assessed long term 2050 goals of the European Union, how they can achieve their goals and methods to help policy makers to achieve their goals. Khanam et al. [11], following implementation of European Energy Policy to reduce greenhouse gas 
(GHG) emissions, conducted a survey 187 experts from five geographical regions of EU countries. The findings showed that 49 percent of the experts perceived that renewable energy target would not be achieved. Child et al. [38] investigated the long-term year 2050 goal of $100 \%$ renewable energy (RE) power sector by 2050. By using simulations, store technologies, modelling proceeds from 2015 to 2050 in five-year time steps, with optimization carried out with regards to the assumed costs and technological status of all technologies involved.

D'Adamo and Rosa [7] proposed a new reference framework to evaluate renewable energy source (RES) with three indicators as renewable energy source share, production per capita and gross final consumption per capital share of energy from renewable energy sources, to help decision makers of energy policy makers. Zappa et al. [43], tested European power system in 2050 with a model of seven scenarios including low-carbon non-renewable technology. Some studies have examined new energy resources to achieve EU's long term 2050 goals, alternative energy resources like biomass energy, tidal (ocean) energy systems, by technical methods to reduce emissions, solar photovoltaic energy and so forth. Verma et al. [44], in their study, indicated that black liquor is an emerging biomass energy resource which ensures a self-sufficient and sustainable process. Segura et al. [34] argued that most of the review papers concerning tidal (ocean) energy systems are focused on engineering topics.

Gerres et al. [35] argued that there are significant discrepancies in the literature regarding the expected emission reductions achievable; they identified the decarbonization of low temperature heat by cross-sector technologies. García-Álvarez et al. [36] indicated that policy makers must consider importance of reducing regulatory uncertainty about feed-in tariff and quota obligation policies. However, there are also studies criticizing the European Union's Energy Policy, such as Blue Growth Energy. Hadjimichael [37] criticized and questioned the EU's Blue Growth strategy (marine aquaculture, coastal tourism, marine biotechnology, ocean energy and seabed mining) from a different perspective, with a limitless economic growth mentality causing marine resources to be unsustainable with overfishing.

In addition to these studies, several studies in the literature focus on energy efficiency and energy saving and renewable energy for energy efficiency and energy saving. Nicolini and Tavoni [13] examined whether the energy policy would increase efficiency and whether it supported renewable electricity in the five largest European countries between 2000 and 2010. They have found that $1 \%$ increase in the incentive tariff will increase in renewable of $0.4-1 \%(18-26 \%)$, showing that the energy policies have been effective in promoting renewable energy. Wang et al. [20] argue in their review between 1998 and 2018 conducting a comprehensive comparative analysis of the differences and challenges in sustainable consumption and production practices within developed and developing economies. Pacesila et al. [10] analysed the renewable energy sector in countries in the EU, based on the share of renewables in total energy produced and the countries' energy dependence, by applying a k-means clustering method based on the data obtained from Eurostat. Gökgöz and Güvercin [14] benchmarked the performance of selected EU countries in renewable energy efficiency and productivity from 2004 to 2014 from an energy security perspective.

In order to increase efficiency, the EU Energy Policy focus on the public transport and construction sector, which has the highest savings potential. Dominković et al. [15] argued that electric transport is the most advantageous and should be the main mode of transport, based on their review of alternative resources needed for the transition towards a completely renewable transport sector, looking at the four main alternatives of biofuels, hydrogen, synthetic fuels and electricity. The results showed that $72.3 \%$ of the transport energy could be converted to electric transport with the existing technology.

Moro and Lonza [16] argue that another methodology the Well-To-Wheels (WTW) is used for policy making in transportation sector, they have calculated that Greenhouse gas (GHG) trade between countries, affect the carbon intensity of electricity consumed at national level. Carrilero et al. [17], in his study on the European Union's several electric battery bus projects, described the advantages and disadvantages of different batteries and charging technologies used in the projects. According to Biresselioglu et al. [18], motivators and barriers are important for EU goals to be achieved. 
Casals et al. [9] argued that electric vehicle emissions changed according to the power plan fleet and efficiency while using, compared to internal combustion engine vehicles. Results show that countries like France or Norway are better suited than countries like Spain and Portugal for electric vehicles adoption. Hasan et al. [19] examined from a different view with life cycle analysis on road networks. Their critical literature review of LCCA (life-cycle cost analysis) and LCA (life-cycle assessment) research based on publications after 2008, examined main 36 and supporting 97 life-cycle cost and environmental articles. According to the results of the literature review, it is understood that there is a need for a new study which focuses on the energy trade performance by using a new methodology, such as fuzzy multicriteria decision making.

\section{Methodology}

\subsection{IT2 Fuzzy DEMATEL}

Interval type-2 fuzzy sets mainly aim to decrease the uncertainty in interval type-1 fuzzy sets [45]. Within this framework, type- 2 fuzzy set is stated as $\widetilde{A}$. In addition to this factor, $\mu_{\widetilde{A}(x, u)}$ represents type- 2 membership function which can be between 0 and 1. The Equations (1) and (2) explain the details of this process.

$$
\begin{gathered}
\widetilde{A}=\left\{\left((x, u), \mu_{\widetilde{A}(x, u)}\right) \mid \forall_{x} \in X, \forall_{u} \in J_{x} \subseteq[0,1]\right\} \text { or } \widetilde{A}=\int_{x \in X} \int_{u \in J_{x}} \mu_{\widetilde{A}}(x, u) /(x, u) J_{x} \subseteq[0,1] \\
\widetilde{A}=\int_{x \in X} \int_{u \in J_{x}} 1 /(x, u) J_{x} \subseteq[0,1]
\end{gathered}
$$

Furthermore, $\widetilde{A}_{i}^{U}$ and $\widetilde{A}_{i}^{L}$ show the upper and lower trapezoidal membership functions. The Equation (3) includes these issues.

$$
\widetilde{A}_{i}=\left(\widetilde{A}_{i}^{U}, \widetilde{A}_{i}^{L}\right)=\left(\left(a_{i 1}^{U}, a_{i 2}^{U}, a_{i 3}^{U}, a_{i 4}^{U} ; H_{1}\left(\widetilde{A}_{i}^{U}\right), H_{2}\left(\widetilde{A}_{i}^{U}\right)\right),\left(a_{i 1}^{L}, a_{i 2}^{L}, a_{i 3}^{L}, a_{i 4}^{L} ; H_{1}\left(\widetilde{A}_{i}^{L}\right), H_{2}\left(\widetilde{A}_{i}^{L}\right)\right)\right)
$$

In addition, the name of DEMATEL comes from the expression of "decision making trial and evaluation laboratory" [46]. This methodology mainly aims to examine the interdependence between the factors [47]. Furthermore, these factors can also be weighted by using DEMATEL approach [48,49]. Firstly, experts of the subject evaluate the conditions. Also, these evaluations are converted to the fuzzy sets [50-53]. Secondly, the initial direct-relation fuzzy matrix $(\widetilde{Z})$ is constructed by considering the Equations (4) and (5) [54].

$$
\begin{gathered}
\widetilde{Z}=\left[\begin{array}{ccccc}
0 & \widetilde{z}_{12} & \cdots & \ldots & \widetilde{z}_{1 n} \\
\widetilde{z}_{21} & 0 & \cdots & \cdots & \widetilde{z}_{2 n} \\
\vdots & \vdots & \ddots & \ldots & \cdots \\
\vdots & \vdots & \vdots & \ddots & \vdots \\
\widetilde{z}_{n 1} & \widetilde{z}_{n 2} & \cdots & \cdots & 0
\end{array}\right] \\
\widetilde{Z}=\frac{\widetilde{Z}^{1}+\widetilde{Z}^{2}+\widetilde{Z}^{3}+\ldots \widetilde{Z}^{n}}{n}
\end{gathered}
$$


After that, the third step includes the normalization of the pairwise matrix. In this context, the Equations (6)-(8) are considered.

$$
\begin{gathered}
\widetilde{X}=\left[\begin{array}{ccccc}
\widetilde{x}_{11} & \widetilde{x}_{12} & \cdots & \cdots & \widetilde{x}_{1 n} \\
\widetilde{x}_{21} & \widetilde{x}_{22} & \cdots & \cdots & \widetilde{x}_{2 n} \\
\vdots & \vdots & \ddots & \cdots & \cdots \\
\vdots & \vdots & \vdots & \ddots & \vdots \\
\widetilde{x}_{n 1} & \widetilde{x}_{n 2} & \cdots & \cdots & \widetilde{x}_{n n}
\end{array}\right] \\
\widetilde{x}_{i j}=\frac{\widetilde{z}_{i j}}{r}=\left(\frac{Z_{a_{i j}^{\prime}}}{r}, \frac{Z_{b_{i j}^{\prime}}}{r}, \frac{Z_{c_{i j}^{\prime}}}{r}, \frac{Z_{d_{i j}^{\prime}}}{r} ; H_{1}\left(z_{i j}^{U}\right), H_{2}\left(z_{i j}^{U}\right)\right),\left(\frac{Z_{e_{i j}^{\prime}}}{r}, \frac{Z_{f_{i j}}}{r}, \frac{Z_{g_{i j}^{\prime}}}{r}, \frac{Z_{h_{i j}}}{r} ; H_{1}\left(z_{i j}^{L}\right), H_{2}\left(z_{i j}^{L}\right)\right) \\
r=\max \left(\max _{1 \leq i \leq n} \sum_{j=1}^{n} Z_{d_{i j}^{\prime}} \max _{1 \leq i \leq n} \sum_{j=1}^{n} Z_{d_{i j}}\right)
\end{gathered}
$$

Next, the total influence fuzzy matrix is generated by using the Equations (9)-(13).

$$
\begin{aligned}
& X_{a}=\left[\begin{array}{ccccc}
0 & a_{12}^{\prime} & \cdots & \cdots & a_{1 n}^{\prime} \\
a^{\prime}{ }_{21} & 0 & \cdots & \cdots & a^{\prime}{ }_{2 n} \\
\vdots & \vdots & \ddots & \cdots & \cdots \\
\vdots & \vdots & \vdots & \ddots & \vdots \\
a_{n 1}^{\prime} & a_{n 2}^{\prime} & \cdots & \cdots & 0
\end{array}\right], \ldots, X_{h}=\left[\begin{array}{ccccc}
0 & h^{\prime}{ }_{12} & \cdots & \cdots & h_{1 n}^{\prime} \\
h^{\prime}{ }_{21} & 0 & \cdots & \cdots & h^{\prime}{ }_{2 n} \\
\vdots & \vdots & \ddots & \cdots & \cdots \\
\vdots & \vdots & \vdots & \ddots & \vdots \\
h_{n 1}^{\prime} & h^{\prime}{ }_{n 2} & \cdots & \cdots & 0
\end{array}\right] \\
& \widetilde{T}=\lim _{k \rightarrow \infty} \widetilde{X}+\widetilde{X}^{2}+\ldots+\widetilde{X}^{k} \\
& \widetilde{T}=\left[\begin{array}{ccccc}
\widetilde{t}_{11} & \widetilde{t}_{12} & \cdots & \cdots & \widetilde{t}_{1 n} \\
\widetilde{t}_{21} & \widetilde{t}_{22} & \cdots & \cdots & \widetilde{t}_{2 n} \\
\vdots & \vdots & \ddots & \cdots & \cdots \\
\vdots & \vdots & \vdots & \ddots & \vdots \\
\widetilde{t}_{n 1} & \widetilde{t}_{n 2} & \cdots & \cdots & \widetilde{t}_{n n}
\end{array}\right] \\
& \widetilde{t}_{i j}=\left(a^{\prime \prime}{ }_{i j}, b^{\prime \prime}{ }_{i j}, c^{\prime \prime}{ }_{i j}, d^{\prime \prime}{ }_{i j} ; H_{1}\left(\widetilde{t}_{i j} U\right), H_{2}\left(\widetilde{t}_{i j}{ }^{U}\right)\right),\left(e^{\prime \prime}{ }_{i j}, f^{\prime \prime}{ }_{i j}, g^{\prime \prime}{ }_{i j}, h^{\prime \prime}{ }_{i j} ; H_{1}\left(\widetilde{t}_{i j}{ }^{L}\right), H_{2}\left(\widetilde{t}_{i j}{ }^{L}\right)\right) \\
& {\left[a^{\prime \prime}{ }_{i j}\right]=X_{\hat{a}} \times\left(I-X_{\hat{a}}\right)^{-1}, \ldots\left[h^{\prime \prime}{ }_{i j}\right]=X_{\hat{h}} \times\left(I-X_{\hat{h}}\right)^{-1}}
\end{aligned}
$$

In the final step, the defuzzified total influence matrix is created with the help of Equations (14)-(17) [55].

$$
\begin{gathered}
D e f_{T}=\frac{\frac{\left(u_{U}-l_{U}\right)+\left(\beta_{U} \times m_{1 U}-l_{U}\right)+\left(\alpha_{U} \times m_{2 U}-l_{U}\right)}{4}+l_{U}+\left[\frac{\left(u_{L}-l_{L}\right)+\left(\beta_{L} \times m_{1 L}-l_{L}\right)+\left(\alpha_{L} \times m_{2 L}-l_{L}\right)}{4}+l_{L}\right]}{2} \\
\operatorname{Def}_{T}=T=\left[t_{i j}\right]_{n \times n^{\prime}} i, j=1,2, \ldots, n \\
\widetilde{D}_{i}^{d e f}=r=\left[\sum_{j=1}^{n} t_{i j}\right]_{n \times 1}=\left(r_{i}\right)_{n \times 1}=\left(r_{1}, \ldots, r_{i}, \ldots, r_{n}\right) \\
\widetilde{R}_{i}^{\text {def }}=y=\left[\sum_{i=1}^{n} t_{i j}\right]_{1 \times n}^{\prime}=\left(y_{j}\right)_{1 \times n}^{\prime}=\left(y_{1}, \ldots, y_{i}, \ldots, y_{n}\right)
\end{gathered}
$$

\subsection{TOPSIS}

TOPSIS refers to the "Technique for Order Preference by Similarity to Ideal Solution" [56]. The main purpose of this method is to rank the alternatives according to their importance [57]. In this 
circumstance, positive and negative ideal solutions are calculated [58]. First of all, the normalized values are calculated as in the Equations (18) and (19).

$$
\begin{gathered}
r_{i j}=\frac{X_{i j}}{\sqrt{\sum_{i=1}^{m} X_{i j}^{2}}} \mathrm{i}=1,2,3, \ldots \mathrm{m} \text { and } \mathrm{j}=1,2,3, \ldots \mathrm{n} \\
v_{i j}=w_{i j} \times r_{i j} \text { where } \mathrm{i}=1,2, \ldots, \mathrm{m} \text { and } \mathrm{j}=1,2, \ldots, \mathrm{n}
\end{gathered}
$$

After that, the positive $\left(A^{+}\right)$and negative $\left(A^{-}\right)$ideal solutions are generater by considering the Equations (20) and (21).

$$
\begin{aligned}
& A^{+}=\left\{v_{1 j}, v_{2 j}, \ldots, v_{m j}\right\}=\left\{\max _{1 j} \text { for } \forall j \in n\right\} \\
& A^{-}=\left\{v_{1 j}, v_{2 j}, \ldots, v_{m j}\right\}=\left\{\min v_{1 j} \text { for } \forall j \in n\right\}
\end{aligned}
$$

In the next step, the distances to the best $\left(D_{i}^{+}\right)$and the worst alternative $\left(D_{i}^{-}\right)$are calculated. In this context, Equations (22) and (23) are used.

$$
\begin{aligned}
& D_{i}^{+}=\sqrt{\sum_{j=1}^{n}\left(v_{i j}-A_{j}^{+}\right)^{2}} \\
& D_{i}^{-}=\sqrt{\sum_{j=1}^{n}\left(v_{i j}-A_{j}^{-}\right)^{2}}
\end{aligned}
$$

Finally, the relative closeness to the ideal solution is identified as is the Equation (24).

$$
R C_{i}=\frac{D_{i}^{-}}{D_{i}^{+}+D_{i}^{-}} \text {for } i=1,2, \ldots, m \text { and } 0 \leq R C_{i} \leq 1
$$

\section{Analysis}

IT2 fuzzy DEMATEL and TOPSIS methods have been combined for the hybrid decision making approach. For that, IT2 fuzzy DEMATEL is used for weighting the factors of international transport including energy trade. In the second stage of the analysis, TOPSIS is selected for ranking the performances of international transport and energy trade in the EU 15 from 2013 and 2016.

\subsection{Analysis Design}

With respect to the relationship between energy and economic growth, there are different views in the literature. According to the neoclassical economists, energy does not have a significant influence on the economic growth. The main reason behind this issue is that energy has a very low ratio in the gross domestic product. On the other side, for some energy economists, energy is accepted as an important input for the production. In other words, it can be used in the production of the final goods. Therefore, for these researchers, energy is a very crucial issue for the economic development.

6 items of international transport and energy trade have been selected to evaluate the performance of EU 15 countries. The factors have been defined by considering the data of ITC Trade Map and the criteria are listed as Sea (criterion 1), Air (criterion 2), Rail (criterion 3), Road (criterion 4), Pipeline (criterion 5) and Electricity (criteria 6) respectively. Additionally, to understand the effect of energy trade in the international transport trade, a comparative analysis has been applied by including and excluding the data of energy trade in the international transport. To weight the relative importance of each criterion, a fuzzy-based model called DEMATEL has been constructed by considering 3 decision makers that are experts in the field of international transport and energy trade. Their linguistic evaluations for the international transport and energy criteria have been collected to measure the 
impact and relationship degrees of the criteria between each other. Table 2 represents the linguistic evaluations and trapezoidal fuzzy numbers for the criteria.

Table 2. Linguistic Scales and fuzzy numbers for the Criteria.

\begin{tabular}{cc}
\hline Linguistic Scales & Interval Type 2 Fuzzy Numbers \\
\hline Very very low $(\mathrm{VVL})$ & $((0,0.1,0.1,0.2 ; 1,1),(0.05,0.1,0.1,0.15 ; 0.9,0.9))$ \\
\hline Very low $(\mathrm{VL})$ & $((0.1,0.2,0.2,0.35 ; 1,1),(0.15,0.2,0.2,0.3 ; 0.9,0.9))$ \\
\hline Low $(\mathrm{L})$ & $((0.2,0.35,0.35,0.5 ; 1,1),(0.25,0.35,0.35,0.45 ; 0.9,0.9))$ \\
\hline Medium $(\mathrm{M})$ & $((0.35,0.5,0.5,0.65 ; 1,1),(0.4,0.5,0.5,0.6 ; 0.9,0.9))$ \\
\hline High $(\mathrm{H})$ & $((0.5,0.65,0.65,0.8 ; 1,1),(0.55,0.65,0.65,0.75 ; 0.9,0.9))$ \\
\hline Very high $(\mathrm{VH})$ & $((0.65,0.8,0.8,0.9 ; 1,1),(0.7,0.8,0.8,0.85 ; 0.9,0.9))$ \\
\hline Very very high $(\mathrm{VVH})$ & $((0.8,0.9,0.9,1 ; 1,1),(0.85,0.9,0.9,0.95 ; 0.9,0.9))$ \\
\hline
\end{tabular}

Table 3 defines the linguistic choices of each criterion provided from the experts for determining the mutual relationship of criterion set.

Table 3. Linguistic choices of the decision makers for the criteria.

\begin{tabular}{|c|c|c|c|c|c|c|c|c|c|}
\hline \multirow{2}{*}{ Criteria } & \multicolumn{3}{|c|}{$\mathrm{C} 1$} & \multicolumn{3}{|c|}{$\mathrm{C} 2$} & \multicolumn{3}{|c|}{$\mathrm{C} 3$} \\
\hline & DM1 & DM2 & DM3 & DM1 & DM2 & DM3 & DM1 & DM2 & DM3 \\
\hline $\mathrm{C} 1$ & - & - & - & $\mathrm{H}$ & $M$ & $\mathrm{M}$ & M & $\mathrm{VH}$ & $\mathrm{H}$ \\
\hline $\mathrm{C} 2$ & $\mathrm{M}$ & $\mathrm{M}$ & $\mathrm{L}$ & - & - & - & $\mathrm{M}$ & $\mathrm{L}$ & $\mathrm{M}$ \\
\hline $\mathrm{C} 3$ & $\mathrm{VH}$ & $\mathrm{H}$ & $\mathrm{H}$ & M & M & $\mathrm{H}$ & - & - & - \\
\hline $\mathrm{C} 4$ & $\mathrm{VH}$ & $\mathrm{H}$ & $\mathrm{M}$ & $\mathrm{H}$ & $\mathrm{VH}$ & $\mathrm{H}$ & $\mathrm{H}$ & $\mathrm{H}$ & $\mathrm{VH}$ \\
\hline C5 & M & $\mathrm{H}$ & $\mathrm{H}$ & $\mathrm{L}$ & $\mathrm{L}$ & $\mathrm{L}$ & M & $\mathrm{M}$ & $\mathrm{L}$ \\
\hline C6 & $\mathrm{L}$ & $\mathrm{M}$ & $\mathrm{L}$ & $\mathrm{L}$ & $\mathrm{L}$ & $\mathrm{L}$ & $\mathrm{L}$ & $\mathrm{L}$ & $\mathrm{M}$ \\
\hline \multirow{2}{*}{ Criteria } & \multicolumn{3}{|c|}{$\mathrm{C} 1$} & \multicolumn{3}{|c|}{$\mathrm{C} 2$} & \multicolumn{3}{|c|}{$\mathrm{C} 3$} \\
\hline & DM1 & DM2 & DM3 & DM1 & DM2 & DM3 & DM1 & DM2 & DM3 \\
\hline $\mathrm{C} 1$ & $\mathrm{H}$ & $\mathrm{VH}$ & $\mathrm{H}$ & $\mathrm{L}$ & $\mathrm{M}$ & $\mathrm{L}$ & $\mathrm{L}$ & $\mathrm{M}$ & $\mathrm{L}$ \\
\hline $\mathrm{C} 2$ & $\mathrm{H}$ & $\mathrm{M}$ & M & $\mathrm{L}$ & $\mathrm{L}$ & $\mathrm{L}$ & $\mathrm{L}$ & $\mathrm{L}$ & $\mathrm{L}$ \\
\hline $\mathrm{C} 3$ & $\mathrm{H}$ & M & $\mathrm{H}$ & $\mathrm{L}$ & $\mathrm{L}$ & $\mathrm{L}$ & $\mathrm{L}$ & $\mathrm{L}$ & $\mathrm{L}$ \\
\hline $\mathrm{C} 4$ & - & - & - & $\mathrm{L}$ & $\mathrm{L}$ & $\mathrm{M}$ & $\mathrm{M}$ & $\mathrm{M}$ & $\mathrm{M}$ \\
\hline $\mathrm{C} 5$ & $\mathrm{VH}$ & $\mathrm{H}$ & M & - & - & - & $\mathrm{H}$ & $\mathrm{M}$ & $\mathrm{H}$ \\
\hline C6 & M & M & M & M & $\mathrm{H}$ & $\mathrm{H}$ & - & - & - \\
\hline
\end{tabular}

The import and export data of 15 European Union countries from 2013 to 2016 have been used for measuring the financial performance of their international transport and energy trade and TOPSIS method is applied for ranking the EU15 countries. For the illustration, the data of 2016 for the transport export and import including the energy trade of the EU 15 countries are seen in Tables 4 and 5 respectively and other data are listed in Appendix A. 
Table 4. Selected Data of Transport Export for the EU by 2016 (US Dollar, Thousand).

\begin{tabular}{ccccccc}
\hline Countries/Criteria & Sea (C1) & Air (C2) & Rail (C3) & Road (C4) & Pipeline (C5) & Electricity (C6) \\
\hline Belgium (A1) & 8677760 & 2717815 & 696876 & 7538424 & 564137 & 362818 \\
\hline Denmark (A2) & 24879865 & 3276379 & 180940 & 2767182 & 98986 & 106175 \\
\hline France (A3) & 12770521 & 12725169 & 1394857 & 6744207 & 1630468 & 975626 \\
\hline Germany (A4) & 24890626 & 18526935 & 1439103 & 6561692 & 59732 & 415913 \\
\hline Luxembourg (A5) & 181409 & 2541937 & 210169 & 1008810 & 2212 & 32078 \\
\hline Netherlands (A6) & 10251593 & 9120663 & 266361 & 10476584 & 512148 & 16703 \\
\hline Sweden (A7) & 3144027 & 3245440 & 189334 & 3475694 & 1217 & 148304 \\
\hline \multicolumn{7}{c}{ Source: ITC, Trade Map [60]. }
\end{tabular}

Table 5. Selected Data of Transport Import for the EU by 2016 (US Dollar, Thousand).

\begin{tabular}{ccccccc}
\hline Countries/Criteria & Sea (C1) & Air (C2) & Rail (C3) & Road (C4) & Pipeline (C5) & Electricity (C6) \\
\hline Belgium (A1) & 6100427 & 3101649 & 524316 & 8671123 & 507724 & 240035 \\
\hline Denmark (A2) & 20216577 & 2911403 & 94451 & 2995347 & 192110 & 152295 \\
\hline France (A3) & 9163361 & 14412051 & 1861653 & 14598990 & 263264 & 362818 \\
\hline Germany (A4) & 18082262 & 19576673 & 1742189 & 13844595 & 667009 & 1262119 \\
\hline Greece (A5) & 1450829 & 1237009 & 15154 & 176210 & 996 & 25220 \\
\hline Luxembourg (A6) & 430293 & 1097302 & 219018 & 914787 & 40928 & 57520 \\
\hline Netherlands (A7) & 4754351 & 5003456 & 529404 & 8843904 & 3318 & 28981 \\
\hline Sweden (A8) & 2518296 & 2911562 & 354448 & 4231702 & 3207 & 131052 \\
\hline
\end{tabular}

Source: ITC, Trade Map [60].

The countries that have the import and export data of transport and energy trade have been considered in the EU 15 for each year. For 2016, Belgium (alternative 1), Denmark (alternative 2), France (alternative 3), Germany (alternative 4), Greece (alternative 5), Luxembourg (alternative 6), Netherlands (alternative 7) and Sweden (alternative 8) have all data of the selected transport and energy import trade. However, Greece has no export data of energy trade, so it is excluded in the export data set of 2016 .

\subsection{Results}

\subsubsection{Weighting the Criteria}

The first step of IT2 fuzzy DEMATEL is to construct the relation matrix based on interval type 2 fuzzy sets. For this purpose, the linguistic evaluations have been converted into the fuzzy numbers and the averaged values have been considered for the matrix in Table 6.

And then the normalized procedure is applied and the results are represented in Table 7.

The following step continues by constructing the total relation matrix and the results are illustrated Table 8. 
Table 6. Direct relation matrix for the criteria.

\begin{tabular}{|c|c|c|c|c|c|c|}
\hline Criteria & $\mathrm{C} 1$ & $\mathrm{C} 2$ & $\mathrm{C} 3$ & $\mathrm{C} 4$ & C5 & C6 \\
\hline $\mathrm{C} 1$ & $((0,0,0,0 ; 1,1),(0,0,0,0 ; 0.90,0.90))$ & $\begin{array}{c}((0.40,0.55,0.55,0.70 ; 1,1) \\
(0.45,0.55,0.55,0.65 ; 0.90,0.90))\end{array}$ & $\begin{array}{c}((0.50,0.65,0.65,0.78 ; 1,1) \\
(0.55,0.65,0.65,0.73 ; 0.90,0.90))\end{array}$ & $\begin{array}{c}((0.55,0.70,0.70,0.83 ; 1,1) \\
(0.60,0.70,0.70,0.78 ; 0.90,0.90))\end{array}$ & $\begin{array}{c}((0.25,0.40,0.40,0.55 ; 1,1) \\
(0.30,0.40,0.40,0.50 ; 0.90,0.90))\end{array}$ & $\begin{array}{c}((0.25,0.40,0.40,0.55 ; 1,1) \\
(0.30,0.40,0.40,0.50 ; 0.90,0.90))\end{array}$ \\
\hline $\mathrm{C} 2$ & $\begin{array}{c}((0.30,0.45,0.45,0.60 ; 1,1) \\
(0.35,0.45,0.45,0.55 ; 0.90,0.90))\end{array}$ & $((0,0,0,0 ; 1,1),(0,0,0,0 ; 0.90,0.90))$ & $\begin{array}{c}((0.30,0.45,0.45,0.60 ; 1,1) \\
(0.35,0.45,0.45,0.55 ; 0.90,0.90))\end{array}$ & $\begin{array}{c}((0.40,0.55,0.55,0.70 ; 1,1) \\
(0.45,0.55,0.55,0.65 ; 0.90,0.90))\end{array}$ & $\begin{array}{c}((0.20,0.35,0.35,0.50 ; 1,1) \\
(0.25,0.35,0.35,0.45 ; 0.90,0.90))\end{array}$ & $\begin{array}{c}((0.20,0.35,0.35,0.50 ; 1,1) \\
(0.25,0.35,0.35,0.45 ; 0.90,0.90))\end{array}$ \\
\hline C3 & $\begin{array}{c}((0.55,0.70,0.70,0.83 ; 1,1) \\
(0.60,0.70,0.70,0.78 ; 0.90,0.90))\end{array}$ & $\begin{array}{c}((0.40,0.55,0.55,0.70 ; 1,1) \\
(0.45,0.55,0.55,0.65 ; 0.90,0.90))\end{array}$ & $((0,0,0,0 ; 1,1),(0,0,0,0 ; 0.90,0.90))$ & $\begin{array}{c}((0.45,0.60,0.60,0.75 ; 1,1) \\
(0.50,0.60,0.60,0.70 ; 0.90,0.90))\end{array}$ & $\begin{array}{c}((0.20,0.35,0.35,0.50 ; 1,1) \\
(0.25,0.35,0.35,0.45 ; 0.90,0.90))\end{array}$ & $\begin{array}{c}((0.20,0.35,0.35,0.50 ; 1,1) \\
(0.25,0.35,0.35,0.45 ; 0.90,0.90))\end{array}$ \\
\hline $\mathrm{C} 4$ & $\begin{array}{c}((0.50,0.65,0.65,0.78 ; 1,1) \\
(0.55,0.65,0.65,0.73 ; 0.90,0.90))\end{array}$ & $\begin{array}{c}((0.55,0.70,0.70,0.83 ; 1,1) \\
(0.60,0.70,0.70,0.78 ; 0.90,0.90))\end{array}$ & $\begin{array}{c}((0.55,0.70,0.70,0.83 ; 1,1) \\
(0.60,0.70,0.70,0.78 ; 0.90,0.90))\end{array}$ & $((0,0,0,0 ; 1,1),(0,0,0,0 ; 0.90,0.90))$ & $\begin{array}{c}((0.25,0.40,0.40,0.55 ; 1,1) \\
(0.30,0.40,0.40,0.50 ; 0.90,0.90))\end{array}$ & $\begin{array}{c}((0.35,0.50,0.50,0.65 ; 1,1) \\
(0.40,0.50,0.50,0.60 ; 0.90,0.90))\end{array}$ \\
\hline $\mathrm{C} 5$ & $\begin{array}{c}((0.45,0.60,0.60,0.75 ; 1,1) \\
(0.50,0.60,0.60,0.70 ; 0.90,0.90))\end{array}$ & $\begin{array}{c}((0.20,0.35,0.35,0.50 ; 1,1) \\
(0.25,0.35,0.35,0.45 ; 0.90,0.90))\end{array}$ & $\begin{array}{c}((0.30,0.45,0.45,0.60 ; 1,1) \\
(0.35,0.45,0.45,0.55 ; 0.90,0.90))\end{array}$ & $\begin{array}{c}((0.50,0.65,0.65,0.78 ; 1,1) \\
(0.55,0.65,0.65,0.73 ; 0.90,0.90))\end{array}$ & $((0,0,0,0 ; 1,1),(0,0,0,0 ; 0.90,0.90))$ & $\begin{array}{c}((0.45,0.60,0.60,0.75 ; 1,1) \\
(0.50,0.60,0.60,0.70 ; 0.90,0.90))\end{array}$ \\
\hline C6 & $\begin{array}{c}((0.25,0.40,0.40,0.55 ; 1,1) \\
(0.30,0.40,0.40,0.50 ; 0.90,0.90))\end{array}$ & $\begin{array}{c}((0.20,0.35,0.35,0.50 ; 1,1) \\
(0.25,0.35,0.35,0.45 ; 0.90,0.90))\end{array}$ & $\begin{array}{c}((0.25,0.40,0.40,0.55 ; 1,1) \\
(0.30,0.40,0.40,0.50 ; 0.90,0.90))\end{array}$ & $\begin{array}{c}((0.35,0.50,0.50,0.65 ; 1,1) \\
(0.40,0.50,0.50,0.60 ; 0.90,0.90))\end{array}$ & $\begin{array}{c}((0.45,0.60,0.60,0.75 ; 1,1) \\
(0.50,0.60,0.60,0.70 ; 0.90,0.90))\end{array}$ & $((0,0,0,0 ; 1,1),(0,0,0,0 ; 0.90,0.90))$ \\
\hline
\end{tabular}

Table 7. The normalized matrix.

\begin{tabular}{|c|c|c|c|c|c|c|}
\hline Criteria & $\mathrm{C} 1$ & $\mathrm{C} 2$ & $\mathrm{C} 3$ & $\mathrm{C} 4$ & C5 & C6 \\
\hline $\mathrm{C} 1$ & $((0,0,0,0 ; 1,1),(0,0,0,0 ; 0.90,0.90))$ & $\begin{array}{c}((0.11,0.15,0.15,0.19 ; 1,1) \\
(0.12,0.15,0.15,0.18 ; 0.90,0.90))\end{array}$ & $\begin{array}{c}((0.14,0.18,0.18,0.21 ; 1,1) \\
(0.15,0.18,0.18,0.20 ; 0.90,0.90))\end{array}$ & $\begin{array}{c}((0.15,0.19,0.19,0.23 ; 1,1) \\
(0.16,0.19,0.19,0.21 ; 0.90,0.90))\end{array}$ & $\begin{array}{c}((0.07,0.11,0.11,0.15 ; 1,1) \\
(0.08,0.11,0.11,0.14 ; 0.90,0.90))\end{array}$ & $\begin{array}{c}((0.07,0.11,0.11,0.15 ; 1,1) \\
(0.08,0.11,0.11,0.14 ; 0.90,0.90)) \\
\end{array}$ \\
\hline $\mathrm{C} 2$ & $\begin{array}{c}((0.08,0.12,0.12,0.16 ; 1,1) \\
(0.10,0.12,0.12,0.15 ; 0.90,0.90)) \\
\end{array}$ & $((0,0,0,0 ; 1,1),(0,0,0,0 ; 0.90,0.90))$ & $\begin{array}{c}((0.08,0.12,0.12,0.16 ; 1,1) \\
(0.10,0.12,0.12,0.15 ; 0.90,0.90))\end{array}$ & $\begin{array}{c}((0.11,0.15,0.15,0.19 ; 1,1) \\
(0.12,0.15,0.15,0.18 ; 0.90,0.90))\end{array}$ & $\begin{array}{c}((0.05,0.10,0.10,0.14 ; 1,1) \\
(0.07,0.10,0.10,0.12 ; 0.90,0.90))\end{array}$ & $\begin{array}{c}((0.05,0.10,0.10,0.14 ; 1,1) \\
(0.07,0.10,0.10,0.12 ; 0.90,0.90))\end{array}$ \\
\hline $\mathrm{C} 3$ & $\begin{array}{c}((0.15,0.19,0.19,0.23 ; 1,1) \\
(0.16,0.19,0.19,0.21 ; 0.90,0.90)) \\
\end{array}$ & $\begin{array}{c}((0.11,0.15,0.15,0.19 ; 1,1) \\
(0.12,0.15,0.15,0.18 ; 0.90,0.90)) \\
\end{array}$ & $((0,0,0,0 ; 1,1),(0,0,0,0 ; 0.90,0.90))$ & $\begin{array}{c}((0.12,0.16,0.16,0.21 ; 1,1) \\
(0.14,0.16,0.16,0.19 ; 0.90,0.90))\end{array}$ & $\begin{array}{c}((0.05,0.10,0.10,0.14 ; 1,1) \\
(0.07,0.10,0.10,0.12 ; 0.90,0.90))\end{array}$ & $\begin{array}{c}((0.05,0.10,0.10,0.14 ; 1,1) \\
(0.07,0.10,0.10,0.12 ; 0.90,0.90))\end{array}$ \\
\hline $\mathrm{C} 4$ & $\begin{array}{c}((0.14,0.18,0.18,0.21 ; 1,1) \\
(0.15,0.18,0.18,0.20 ; 0.90,0.90))\end{array}$ & $\begin{array}{c}((0.15,0.19,0.19,0.23 ; 1,1) \\
(0.16,0.19,0.19,0.21 ; 0.90,0.90))\end{array}$ & $\begin{array}{c}((0.15,0.19,0.19,0.23 ; 1,1) \\
(0.16,0.19,0.19,0.21 ; 0.90,0.90))\end{array}$ & $((0,0,0,0 ; 1,1),(0,0,0,0 ; 0.90,0.90))$ & $\begin{array}{c}((0.07,0.11,0.11,0.15 ; 1,1) \\
(0.08,0.11,0.11,0.14 ; 0.90,0.90))\end{array}$ & $\begin{array}{c}((0.10,0.14,0.14,0.18 ; 1,1) \\
(0.11,0.14,0.14,0.16 ; 0.90,0.90))\end{array}$ \\
\hline C5 & $\begin{array}{c}((0.12,0.16,0.16,0.21 ; 1,1) \\
(0.14,0.16,0.16,0.19 ; 0.90,0.90)) \\
\end{array}$ & $\begin{array}{c}((0.05,0.10,0.10,0.14 ; 1,1) \\
(0.07,0.10,0.10,0.12 ; 0.90,0.90)) \\
\end{array}$ & $\begin{array}{c}((0.08,0.12,0.12,0.16 ; 1,1) \\
(0.10,0.12,0.12,0.15 ; 0.90,0.90))\end{array}$ & $\begin{array}{c}((0.14,0.18,0.18,0.21 ; 1,1) \\
(0.15,0.18,0.18,0.20 ; 0.90,0.90))\end{array}$ & $((0,0,0,0 ; 1,1),(0,0,0,0 ; 0.90,0.90))$ & $\begin{array}{c}((0.12,0.16,0.16,0.21 ; 1,1) \\
(0.14,0.16,0.16,0.19 ; 0.90,0.90))\end{array}$ \\
\hline C6 & $\begin{array}{c}((0.07,0.11,0.11,0.15 ; 1,1) \\
(0.08,0.11,0.11,0.14 ; 0.90,0.90))\end{array}$ & $\begin{array}{c}((0.05,0.10,0.10,0.14 ; 1,1) \\
(0.07,0.10,0.10,0.12 ; 0.90,0.90))\end{array}$ & $\begin{array}{c}((0.07,0.11,0.11,0.15 ; 1,1) \\
(0.08,0.11,0.11,0.14 ; 0.90,0.90))\end{array}$ & $\begin{array}{c}((0.10,0.14,0.14,0.18 ; 1,1) \\
(0.11,0.14,0.14,0.16 ; 0.90,0.90))\end{array}$ & $\begin{array}{c}((0.12,0.16,0.16,0.21 ; 1,1) \\
(0.14,0.16,0.16,0.19 ; 0.90,0.90))\end{array}$ & $((0,0,0,0 ; 1,1),(0,0,0,0 ; 0.90,0.90))$ \\
\hline
\end{tabular}


Table 8. Total relation matrix.

\begin{tabular}{|c|c|c|c|c|c|c|}
\hline Criteria & $\mathrm{C} 1$ & $\mathrm{C} 2$ & C3 & C4 & C5 & C6 \\
\hline $\mathrm{C} 1$ & $\begin{array}{c}((0.11,0.33,0.33,1.50 ; 1,1) \\
(0.16,0.33,0.33,0.78 ; 0.90,0.90))\end{array}$ & $\begin{array}{c}((0.20,0.44,0.44,1.58 ; 1,1) \\
(0.25,0.44,0.44,0.88 ; 0.90,0.90))\end{array}$ & $\begin{array}{c}((0.23,0.47,0.47,1.64 ; 1,1) \\
(0.28,0.47,0.47,0.92 ; 0.90,0.90))\end{array}$ & $\begin{array}{c}((0.25,0.51,0.51,1.76 ; 1,1) \\
(0.31,0.51,0.51,1.00 ; 0.90,0.90))\end{array}$ & $\begin{array}{c}((0.13,0.35,0.35,1.37 ; 1,1) \\
(0.18,0.35,0.35,0.75 ; 0.90,0.90))\end{array}$ & $\begin{array}{c}((0.14,0.36,0.36,1.41 ; 1,1) \\
(0.19,0.36,0.36,0.77 ; 0.90,0.90))\end{array}$ \\
\hline C2 & $\begin{array}{c}((0.16,0.38,0.38,1.45 ; 1,1) \\
(0.21,0.38,0.38,0.80 ; 0.90,0.90))\end{array}$ & $\begin{array}{c}((0.07,0.25,0.25,1.23 ; 1,1) \\
(0.11,0.25,0.25,0.63 ; 0.90,0.90))\end{array}$ & $\begin{array}{c}((0.15,0.37,0.37,1.41 ; 1,1) \\
(0.20,0.37,0.37,0.78 ; 0.90,0.90))\end{array}$ & $\begin{array}{c}((0.18,0.42,0.42,1.53 ; 1,1) \\
(0.24,0.42,0.42,0.85 ; 0.90,0.90))\end{array}$ & $\begin{array}{c}((0.10,0.29,0.29,1.20 ; 1,1) \\
(0.15,0.29,0.29,0.65 ; 0.90,0.90))\end{array}$ & $\begin{array}{c}((0.11,0.30,0.30,1.24 ; 1,1) \\
(0.15,0.30,0.30,0.67 ; 0.90,0.90))\end{array}$ \\
\hline C3 & $\begin{array}{c}((0.24,0.50,0.50,1.76 ; 1,1) \\
(0.30,0.50,0.50,0.99 ; 0.90,0.90))\end{array}$ & $\begin{array}{c}((0.19,0.42,0.42,1.53 ; 1,1) \\
(0.25,0.42,0.42,0.86 ; 0.90,0.90))\end{array}$ & $\begin{array}{c}((0.10,0.30,0.30,1.41 ; 1,1) \\
(0.14,0.30,0.30,0.73 ; 0.90,0.90))\end{array}$ & $\begin{array}{c}((0.22,0.47,0.47,1.69 ; 1,1) \\
(0.28,0.47,0.47,0.95 ; 0.90,0.90))\end{array}$ & $\begin{array}{c}((0.12,0.33,0.33,1.32 ; 1,1) \\
(0.17,0.33,0.33,0.72 ; 0.90,0.90))\end{array}$ & $\begin{array}{c}((0.12,0.34,0.34,1.36 ; 1,1) \\
(0.17,0.34,0.34,0.74 ; 0.90,0.90))\end{array}$ \\
\hline C4 & $\begin{array}{c}((0.24,0.50,0.50,1.76 ; 1,1) \\
(0.30,0.50,0.50,0.99 ; 0.90,0.90))\end{array}$ & $\begin{array}{c}((0.24,0.49,0.49,1.67 ; 1,1) \\
(0.30,0.49,0.49,0.95 ; 0.90,0.90))\end{array}$ & $\begin{array}{c}(0.25,0.50,0.50,1.72 ; 1,1) \\
(0.30,0.50,0.50,0.97 ; 0.90,0.90))\end{array}$ & $\begin{array}{c}((0.13,0.37,0.37,1.65 ; 1,1) \\
(0.18,0.37,0.37,0.86 ; 0.90,0.90))\end{array}$ & $\begin{array}{c}(0.14,0.37,0.37,1.44 ; 1,1) \\
(0.19,0.37,0.37,0.79 ; 0.90,0.90))\end{array}$ & $\begin{array}{c}((0.17,0.40,0.40,1.50 ; 1,1) \\
(0.22,0.40,0.40,0.83 ; 0.90,0.90))\end{array}$ \\
\hline C5 & $\begin{array}{c}((0.22,0.47,0.47,1.66 ; 1,1) \\
(0.27,0.47,0.47,0.94 ; 0.90,0.90))\end{array}$ & $\begin{array}{c}((0.15,0.39,0.39,1.52 ; 1,1) \\
(0.20,0.39,0.39,0.84 ; 0.90,0.90))\end{array}$ & $\begin{array}{c}((0.18,0.42,0.42,1.59 ; 1,1) \\
(0.24,0.42,0.42,0.88 ; 0.90,0.90))\end{array}$ & $\begin{array}{c}((0.24,0.50,0.50,1.74 ; 1,1) \\
(0.30,0.50,0.50,0.98 ; 0.90,0.90))\end{array}$ & $\begin{array}{c}((0.07,0.25,0.25,1.24 ; 1,1) \\
(0.11,0.25,0.25,0.63 ; 0.90,0.90))\end{array}$ & $\begin{array}{c}((0.19,0.40,0.40,1.45 ; 1,1) \\
(0.24,0.40,0.40,0.81 ; 0.90,0.90))\end{array}$ \\
\hline C6 & $\begin{array}{c}((0.15,0.38,0.38,1.48 ; 1,1) \\
(0.20,0.38,0.38,0.81 ; 0.90,0.90))\end{array}$ & $\begin{array}{c}((0.13,0.34,0.34,1.38 ; 1,1) \\
(0.18,0.34,0.34,0.76 ; 0.90,0.90))\end{array}$ & $\begin{array}{c}((0.14,0.37,0.37,1.44 ; 1,1) \\
(0.20,0.37,0.37,0.79 ; 0.90,0.90))\end{array}$ & $\begin{array}{c}((0.18,0.42,0.42,1.56 ; 1,1) \\
(0.23,0.42,0.42,0.87 ; 0.90,0.90))\end{array}$ & $\begin{array}{c}((0.17,0.36,0.36,1.29 ; 1,1) \\
(0.21,0.36,0.36,0.72 ; 0.90,0.90))\end{array}$ & $\begin{array}{c}((0.06,0.23,0.23,1.15 ; 1,1) \\
(0.10,0.23,0.23,0.58 ; 0.90,0.90))\end{array}$ \\
\hline
\end{tabular}


The final step of IT2 fuzzy DEMATEL is the defuzzification process to obtain the weight results of criteria. The defuzzified total relation matrix and the final weights are represented in Table 9.

Table 9. Defuzzified values of matrix and weights of criteria.

\begin{tabular}{cccccccccccc}
\hline Criteria & $\mathbf{C 1}$ & $\mathbf{C 2}$ & $\mathbf{C 3}$ & $\mathbf{C 4}$ & $\mathbf{C 5}$ & $\mathbf{C 6}$ & $\mathbf{R}$ & $\mathbf{y}$ & $\mathbf{r + y}$ & $\mathbf{r}-\mathbf{y}$ & Weights \\
\hline C1 & 0.48 & 0.57 & 0.61 & 0.66 & 0.47 & 0.49 & 3.27 & 3.37 & 6.64 & -0.10 & 0.178 \\
\hline C2 & 0.51 & 0.37 & 0.49 & 0.55 & 0.40 & 0.41 & 2.74 & 3.12 & 5.86 & -0.38 & 0.157 \\
\hline C3 & 0.61 & 0.55 & 0.44 & 0.62 & 0.44 & 0.46 & 3.13 & 3.25 & 6.38 & -0.12 & 0.171 \\
\hline C4 & 0.65 & 0.63 & 0.64 & 0.53 & 0.49 & 0.53 & 3.47 & 3.54 & 7.02 & -0.07 & 0.188 \\
\hline C5 & 0.61 & 0.52 & 0.56 & 0.64 & 0.37 & 0.53 & 3.23 & 2.65 & 5.89 & 0.58 & 0.158 \\
\hline C6 & 0.51 & 0.47 & 0.50 & 0.55 & 0.47 & 0.34 & 2.84 & 2.76 & 5.60 & 0.08 & 0.150 \\
\hline
\end{tabular}

Table 9 shows that road (C4) is the most important item in the international transport and energy trade while electricity (C6) has the weakest importance relatively among the criterion set. Additionally, pipeline (C5) is the most influencing factor as air (C2) is the most influenced factor in the criteria. It is determined that road and sea have the highest importance for international transport and energy trade. However, pipeline and electricity, which explain the energy trade, take place on the last ranks. This situation gives information that energy trade factors have lower importance by comparing with others.

\subsubsection{Ranking Alternatives}

Second stage of the hybrid decision making model is to rank the 15 European Union countries with TOPSIS method dynamically. For this purpose, the data set of international transport and energy import and export in the EU 15 has been used for measuring their performances between 2013 and 2016 (see for details in Table 4 and 5 as well as Appendix A). Analysis details of international transport and energy export for 2016 are provided as follows:

Initially, the decision matrix has been normalized and results are defined in Table 10.

Table 10. Normalized criterion matrix for the international transport and energy export in 2016.

\begin{tabular}{ccccccc}
\hline Countries/Criteria & C1 & C2 & C3 & C4 & C5 & C6 \\
\hline Belgium (A1) & 0.217 & 0.109 & 0.322 & 0.454 & 0.313 & 0.319 \\
\hline Denmark (A2) & 0.624 & 0.131 & 0.084 & 0.167 & 0.055 & 0.093 \\
\hline France (A3) & 0.320 & 0.510 & 0.644 & 0.406 & 0.904 & 0.859 \\
\hline Germany (A4) & 0.624 & 0.742 & 0.665 & 0.395 & 0.033 & 0.366 \\
\hline Luxembourg (A5) & 0.005 & 0.102 & 0.097 & 0.061 & 0.001 & 0.028 \\
\hline Netherlands (A6) & 0.257 & 0.365 & 0.123 & 0.631 & 0.284 & 0.015 \\
\hline Sweden (A7) & 0.079 & 0.130 & 0.087 & 0.209 & 0.001 & 0.131 \\
\hline
\end{tabular}

The weighting results provided from IT2 Fuzzy DEMATEL have been used for the weighted criterion matrix as seen in Table 11. 
Table 11. The weighted criterion matrix.

\begin{tabular}{ccccccc}
\hline Countries/Criteria & C1 & C2 & C3 & C4 & C5 & C6 \\
\hline Belgium (A1) & 0.039 & 0.017 & 0.055 & 0.085 & 0.049 & 0.048 \\
\hline Denmark (A2) & 0.111 & 0.021 & 0.014 & 0.031 & 0.009 & 0.014 \\
\hline France (A3) & 0.057 & 0.080 & 0.110 & 0.076 & 0.142 & 0.129 \\
\hline Germany (A4) & 0.111 & 0.116 & 0.113 & 0.074 & 0.005 & 0.055 \\
\hline Luxembourg (A5) & 0.001 & 0.016 & 0.017 & 0.011 & 0.000 & 0.004 \\
\hline Netherlands (A6) & 0.046 & 0.057 & 0.021 & 0.118 & 0.045 & 0.002 \\
\hline Sweden (A7) & 0.014 & 0.020 & 0.015 & 0.039 & 0.000 & 0.020 \\
\hline
\end{tabular}

Finally, the values of $D_{i}^{+}, D_{i}^{-}$and the relative closeness $\left(R C_{i}\right)$ have been calculated to rank the European Union countries. The results are illustrated in Table 12.

Table 12. The values of weighted criterion matrix.

\begin{tabular}{ccccc}
\hline Countries/Criteria & $\boldsymbol{D}_{\boldsymbol{i}}{ }^{+}$ & $\boldsymbol{D}_{\boldsymbol{i}}{ }^{-}$ & $\boldsymbol{R} \boldsymbol{C}_{\boldsymbol{i}}$ & Ranking \\
\hline Belgium (A1) & 0.186 & 0.114 & 0.380 & 4 \\
\hline Denmark (A2) & 0.240 & 0.113 & 0.320 & 5 \\
\hline France (A3) & 0.078 & 0.238 & 0.754 & 1 \\
\hline Germany (A4) & 0.162 & 0.197 & 0.549 & 2 \\
\hline Luxembourg (A5) & 0.281 & 0.003 & 0.011 & 7 \\
\hline Netherlands (A6) & 0.204 & 0.131 & 0.391 & 3 \\
\hline Sweden (A7) & 0.258 & 0.036 & 0.121 & 6 \\
\hline
\end{tabular}

According to the results, France (A3) is the best country in the international transport export including the energy trade (pipeline and electricity) while Luxembourg (A5) is the worst place in the overall transport export. Same analysis procedure has been applied for 2013, 2014 and 2015 and the ranking results are provided in Tables 13-15 respectively.

Table 13. Ranking results of the international transport export including energy trade for the selected EU countries in 2013.

\begin{tabular}{ccccc}
\hline Countries & $\boldsymbol{D}_{\boldsymbol{i}}{ }^{+}$ & $\boldsymbol{D}_{\boldsymbol{i}}{ }^{-}$ & $\boldsymbol{R} \boldsymbol{C}_{\boldsymbol{i}}$ & Ranking \\
\hline Belgium (A1) & 0.209 & 0.138 & 0.398 & 2 \\
\hline Denmark (A2) & 0.260 & 0.159 & 0.379 & 3 \\
\hline France (A3) & 0.088 & 0.294 & 0.769 & 1 \\
\hline Luxembourg (A4) & 0.325 & 0.000 & 0.001 & 5 \\
\hline Sweden (A5) & 0.287 & 0.059 & 0.171 & 4 \\
\hline
\end{tabular}

Table 14. Ranking results of the international transport export including energy trade for the selected EU countries in 2014.

\begin{tabular}{ccccc}
\hline Countries & $\boldsymbol{D}_{\boldsymbol{i}}^{+}$ & $\boldsymbol{D}_{\boldsymbol{i}}{ }^{-}$ & $\boldsymbol{R} \boldsymbol{C}_{\boldsymbol{i}}$ & Ranking \\
\hline Belgium (A1) & 0.214 & 0.120 & 0.360 & 4 \\
\hline Denmark (A2) & 0.252 & 0.151 & 0.374 & 3 \\
\hline France (A3) & 0.094 & 0.267 & 0.740 & 1 \\
\hline Luxembourg (A4) & 0.311 & 0.004 & 0.012 & 6 \\
\hline Netherlands (A5) & 0.219 & 0.156 & 0.415 & 2 \\
\hline Sweden (A6) & 0.285 & 0.040 & 0.123 & 5 \\
\hline
\end{tabular}


Table 15. Ranking results of the international transport export including energy trade for the selected EU countries in 2015.

\begin{tabular}{ccccc}
\hline Countries & $\boldsymbol{D}_{\boldsymbol{i}}{ }^{+}$ & $\boldsymbol{D}_{\boldsymbol{i}}{ }^{-}$ & $\boldsymbol{R} \boldsymbol{C}_{\boldsymbol{i}}$ & Ranking \\
\hline Belgium (A1) & 0.206 & 0.128 & 0.384 & 3 \\
\hline Denmark (A2) & 0.256 & 0.148 & 0.366 & 4 \\
\hline France (A3) & 0.089 & 0.270 & 0.753 & 1 \\
\hline Luxembourg (A4) & 0.309 & 0.007 & 0.022 & 6 \\
\hline Netherlands (A5) & 0.226 & 0.147 & 0.395 & 2 \\
\hline Sweden (A6) & 0.285 & 0.043 & 0.131 & 5 \\
\hline
\end{tabular}

Overall results show that France is the best country from 2013 to 2016 as Luxembourg has the worst performance in the international transport export including energy trade. To obtain the comprehensive analysis results, the comparative analysis results of the international transport export by including and excluding the effects of energy trade are represented in Table 16.

The overall results illustrate that there is almost no difference in the ranking of international transport performance including and excluding energy trade. However, by 2016, it is understood that Germany firstly stated in the ranking list with the energy export and France is the second in the list if the energy trade is not considered in the international transport export. Additionally, by 2013, Netherlands has entered the list with the energy trade and listed in the high degrees during the period. Similarly, the ranking results of international transport import including and excluding energy trade have been computed and the comprehensive results are illustrated in Table 17.

Table 17 represents the ranking performance of the selected European Union countries for the international transport import with the effect of energy trade. According to the results, Greece enter the ranking list in case of energy import in the international transport and placed in last for each year. The European Union Countries have also the similar ranking results for the international transport performance including and excluding energy import. France has the best performance in the energy import except 2016. Similarly, Germany is ranked as first for including and excluding the energy import by 2016. This situation gives information that France and Germany are the countries which use road and sea transport more effectively in comparison with other countries. Similarly, it means that the countries which are on the last ranks, are not so successful to use road and sea transport. As a result, it is seen that European countries have the highest degrees of industry development also needs the most transportation and energy import to increase their availability for the sustainable growth. However, the countries with the low gross domestic product import the services of transport and energy trade weakly. 
Table 16. Ranking transport export performance of the EU countries in case of including and excluding the energy trade.

\begin{tabular}{|c|c|c|c|c|c|c|c|c|c|c|c|}
\hline \multicolumn{3}{|c|}{2013} & \multicolumn{3}{|l|}{2014} & \multicolumn{3}{|l|}{2015} & \multicolumn{3}{|l|}{2016} \\
\hline Energy Export & Inc. & Exc. & Energy Export & Inc. & Exc. & Energy Export & Inc. & Exc. & Energy Export & Inc. & Exc. \\
\hline Belgium (A1) & 2 & 3 & Belgium (A1) & 4 & 4 & Belgium (A1) & 3 & 4 & Belgium (A1) & 4 & 5 \\
\hline Denmark (A2) & 3 & 2 & Denmark (A2) & 3 & 3 & Denmark (A2) & 4 & 3 & Denmark (A2) & 5 & 4 \\
\hline France (A3) & 1 & 1 & France (A3) & 1 & 1 & France (A3) & 1 & 1 & France (A3) & 1 & 2 \\
\hline Luxem. (A4) & 5 & 5 & Luxem. (A4) & 6 & 6 & Luxem. (A4) & 6 & 6 & Germany (A4) & 2 & 1 \\
\hline \multirow[t]{3}{*}{ Sweden (A5) } & 4 & 4 & Netherlands (A5) & 2 & 2 & Netherlands (A5) & 2 & 2 & Luxem. (A5) & 7 & 7 \\
\hline & & & Sweden (A6) & 5 & 5 & Sweden (A6) & 5 & 5 & Netherlands (A6) & 3 & 3 \\
\hline & & & & & & & & & Sweden (A7) & 6 & 6 \\
\hline
\end{tabular}

Table 17. Ranking transport import performance of the EU countries in case of including and excluding the energy trade.

\begin{tabular}{cccccccccccc}
\hline \multicolumn{1}{c}{$\mathbf{2 0 1 3}$} & \multicolumn{2}{c}{$\mathbf{2 0 1 4}$} & \multicolumn{2}{c}{$\mathbf{2 0 1 5}$} & & $\mathbf{2 0 1 6}$ \\
\hline Energy Import & Inc. & Exc. & Energy Import & Inc. & Exc. & Energy Import & Inc. & Exc. & Energy Import & Inc. & Exc. \\
\hline Belgium (A1) & 2 & 3 & Belgium (A1) & 2 & 4 & Belgium (A1) & 2 & 4 & Belgium (A1) & 3 & 5 \\
\hline Denmark (A2) & 3 & 2 & Denmark (A2) & 3 & 2 & Denmark (A2) & 3 & 2 & Denmark (A2) & 4 & 3 \\
\hline France (A3) & 1 & 1 & France (A3) & 1 & 1 & France (A3) & 1 & 1 & France (A3) & 2 & 2 \\
\hline Greece (A4) & 6 & 6 & Greece (A4) & 7 & 7 & Greece (A4) & 7 & 7 & Germany (A4) & 1 & 1 \\
\hline Luxembourg (A5) & 5 & 5 & Luxembourg (A5) & 6 & 6 & Luxembourg (A5) & 6 & 6 & Greece (A5) & 8 & 8 \\
\hline Sweden (A6) & 4 & 4 & Netherlands (A6) & 4 & 3 & Netherlands (A6) & 4 & 3 & Luxembourg (A6) & 7 & 7 \\
\hline & & & Sweden (A7) & 5 & 5 & Sweden (A7) & 5 & 5 & Netherlands (A7) & 5 & 4 \\
\hline & & & & & & & Sweden (A8) & 6 & 6 \\
\hline
\end{tabular}




\section{Conclusions}

This study aims to identify the role of energy trade in the international trade for European countries. For this purpose, 6 items of international transport and energy trade have been selected to evaluate the performance of EU 15 countries. In this process, the data of ITC Trade Map is taken into the consideration and sea, air, rail, road, pipeline and electricity are selected as the criteria. In addition to these issues, a dynamic analysis is performed in order to achieve this objective. A comparative analysis has been applied by including and excluding the data of energy trade in the international transport for the years between 2013 and 2016.

The criteria are weighted by using interval type-2 fuzzy DEMATEL approach. It is concluded that road and sea have the highest importance for international transport and energy trade. On the other side, pipeline and electricity, which explain the energy trade, take place on the last ranks. These results explain that energy trade factors are less important than others. Lee et al. [61], Schneider [62] and Hilmola [63] also underlined the importance of road and sea with respect to international transport in their studies. Thus, it is recommended that European countries should give more importance to the energy production because it has significant effects on both international trade volume and industrial production. In this context, renewable energy issues should be focused on since they lead to cost minimization.

In addition to these conditions, European countries are ranked with respect to the international transport and energy trade. In this framework, TOPSIS approach is used. It is identified that France is the best country from 2013 to 2016 while Luxembourg has the worst performance in the international transport export including energy trade. Another important conclusion is that there is almost no difference in the ranking of international transport performance including and excluding energy trade. However, in case of excluding energy trade, Germany has the best performance in 2016 while France is on the second place. It is understood that use road and sea transport are used more effectively by France and Germany by comparing with other countries. Additionally, German has a very outstanding performance in international transport but France becomes better than Germany in case of including energy trade. In the future studies, more countries can be analysed using different methodologies, such as interval type-2 Vise Kriterijumska Optimizacija I Kompromisno Resenje (VIKOR) and qualitative flexible (QUALIFLEX).

Author Contributions: Conceptualization, S.Y. and H.D.; Methodology, Y.M.; Software, H.D.; Validation, S.Y. and H.D.; Formal Analysis, H.D.; Investigation, S.Y.; Resources, Y.M.; Data Curation, H.D.; Writing-Original Draft Preparation, S.Y.; Writing-Review and Editing, H.D.; Visualization, Y.M.; Supervision, S.Y.; Project Administration, H.D.; Funding Acquisition, Y.M.

Funding: This research received no external funding.

Conflicts of Interest: The authors declare no conflict of interest.

\section{Appendix A}

Table A1. Selected Data of Transport Export for the EU by 2016 (US Dollar, Thousand).

\begin{tabular}{ccccccc}
\hline Countries/Criteria & Sea (C1) & Air (C2) & Rail (C3) & Road (C4) & Pipeline (C5) & Electricity (C6) \\
\hline Belgium (A1) & 8677760 & 2717815 & 696876 & 7538424 & 564137 & 362818 \\
\hline Denmark (A2) & 24879865 & 3276379 & 180940 & 2767182 & 98986 & 106175 \\
\hline France (A3) & 12770521 & 12725169 & 1394857 & 6744207 & 1630468 & 975626 \\
\hline Germany (A4) & 24890626 & 18526935 & 1439103 & 6561692 & 59732 & 415913 \\
\hline Luxembourg (A5) & 181409 & 2541937 & 210169 & 1008810 & 2212 & 32078 \\
\hline Netherlands (A6) & 10251593 & 9120663 & 266361 & 10476584 & 512148 & 16703 \\
\hline Sweden (A7) & 3144027 & 3245440 & 189334 & 3475694 & 1217 & 148304 \\
\hline \multicolumn{7}{c}{ Source: ITC, Trade Map. }
\end{tabular}


Table A2. Selected Data of Transport Export for the EU by 2015 (US Dollar, Thousand).

\begin{tabular}{ccccccc}
\hline Countries/Criteria & Sea (C1) & Air (C2) & Rail (C3) & Road (C4) & Pipeline (C5) & Electricity (C6) \\
\hline Belgium (A1) & 8657375 & 2744940 & 713130 & 7744613 & 596678 & 320520 \\
\hline Denmark (A2) & 30191746 & 3236176 & 148223 & 2673329 & 100774 & 134476 \\
\hline France (A3) & 14554283 & 12462583 & 1316462 & 6661055 & 1548257 & 1107958 \\
\hline Luxembourg (A4) & 247322 & 2835884 & 210723 & 1007033 & 3327 & 39926 \\
\hline Netherlands (A5) & 11008153 & 9562374 & 280150 & 10399830 & 445290 & 47135 \\
\hline Sweden (A6) & 3699443 & 3327070 & 187961 & 4091666 & 1442 & 113553 \\
\hline \multicolumn{7}{c}{ Source: ITC, Trade Map. }
\end{tabular}

Table A3. Selected Data of Transport Export for the EU by 2014 (US Dollar, Thousand).

\begin{tabular}{ccccccc}
\hline Countries/Criteria & Sea (C1) & Air (C2) & Rail (C3) & Road (C4) & Pipeline (C5) & Electricity (C6) \\
\hline Belgium (A1) & 8987294 & 3148339 & 792060 & 8025412 & 825228 & 220238 \\
\hline Denmark (A2) & 36698422 & 4054771 & 198973 & 3108786 & 62694 & 191667 \\
\hline France (A3) & 16759301 & 14365873 & 1462061 & 8415472 & 1684952 & 1125070 \\
\hline Luxembourg (A4) & 294535 & 3281011 & 236159 & 1184773 & 1327 & 30515 \\
\hline Netherlands (A5) & 13653152 & 11382977 & 280472 & 13051080 & 575802 & 94596 \\
\hline Sweden (A6) & 3810989 & 3480643 & 249849 & 4543826 & 2122 & 133544 \\
\hline
\end{tabular}

Source: ITC, Trade Map.

Table A4. Selected Data of Transport Export for the EU by 2013 (US Dollar, Thousand).

\begin{tabular}{ccccccc}
\hline Countries/Criteria & Sea (C1) & Air (C2) & Rail (C3) & Road (C4) & Pipeline (C5) & Electricity (C6) \\
\hline Belgium (A1) & 10340446 & 2759046 & 762123 & 6239054 & 641299 & 519147 \\
\hline Denmark (A2) & 35481896 & 4163233 & 214190 & 2935324 & 47672 & 130665 \\
\hline France (A3) & 15518636 & 13157912 & 1937174 & 8897192 & 1303842 & 981201 \\
\hline Luxembourg (A4) & 252271 & 2670087 & 219077 & 1132563 & 2655 & 27883 \\
\hline Sweden (A5) & 4279418 & 3913381 & 322872 & 4525656 & 1727 & 135338 \\
\hline
\end{tabular}

Source: ITC, Trade Map.

Table A5. Selected Data of Transport Import for the EU by 2016 (US Dollar, Thousand).

\begin{tabular}{ccccccc}
\hline Countries/Criteria & Sea (C1) & Air (C2) & Rail (C3) & Road (C4) & Pipeline (C5) & Electricity (C6) \\
\hline Belgium (A1) & 6100427 & 3101649 & 524316 & 8671123 & 507724 & 240035 \\
\hline Denmark (A2) & 20216577 & 2911403 & 94451 & 2995347 & 192110 & 152295 \\
\hline France (A3) & 9163361 & 14412051 & 1861653 & 14598990 & 263264 & 362818 \\
\hline Germany (A4) & 18082262 & 19576673 & 1742189 & 13844595 & 667009 & 1262119 \\
\hline Greece (A5) & 1450829 & 1237009 & 15154 & 176210 & 996 & 25220 \\
\hline Luxembourg (A6) & 430293 & 1097302 & 219018 & 914787 & 40928 & 57520 \\
\hline Netherlands (A7) & 4754351 & 5003456 & 529404 & 8843904 & 3318 & 28981 \\
\hline Sweden (A8) & 2518296 & 2911562 & 354448 & 4231702 & 3207 & 131052 \\
\hline
\end{tabular}

Source: ITC, Trade Map. 
Table A6. Selected Data of Transport Import for the EU by 2015 (US Dollar, Thousand).

\begin{tabular}{ccccccc}
\hline Countries/Criteria & Sea (C1) & Air (C2) & Rail (C3) & Road (C4) & Pipeline (C5) & Electricity (C6) \\
\hline Belgium (A1) & 5967888 & 3366018 & 585587 & 8021880 & 595569 & 192978 \\
\hline Denmark (A2) & 22163333 & 2994497 & 107315 & 2859134 & 169397 & 80153 \\
\hline France (A3) & 9898421 & 14097348 & 1780052 & 13744665 & 326066 & 430318 \\
\hline Greece (A4) & 2352774 & 1327997 & 10314 & 152718 & 1885 & 26950 \\
\hline Luxembourg (A5) & 446954 & 1140121 & 222922 & 1276536 & 43254 & 75417 \\
\hline Netherlands (A6) & 4985255 & 4796825 & 558415 & 8711165 & 6987 & 41812 \\
\hline Sweden (A7) & 2836820 & 2791687 & 337442 & 4817005 & 444 & 76182 \\
\hline \multicolumn{7}{c}{ Source: ITC, Trade Map. }
\end{tabular}

Table A7. Selected Data of Transport Import for the EU by 2014 (US Dollar, Thousand).

\begin{tabular}{ccccccc}
\hline Countries/Criteria & Sea (C1) & Air (C2) & Rail (C3) & Road (C4) & Pipeline (C5) & Electricity (C6) \\
\hline Belgium (A1) & 6536817 & 3996121 & 740317 & 8467215 & 802674 & 90218 \\
\hline Denmark (A2) & 24932851 & 3472862 & 132958 & 3400339 & 132162 & 141991 \\
\hline France (A3) & 11092821 & 17077717 & 1708833 & 15800072 & 372812 & 455070 \\
\hline Greece (A4) & 3841158 & 1278838 & 14992 & 166770 & 3848 & 37281 \\
\hline Luxembourg (A5) & 481604 & 1326733 & 253406 & 2853804 & 35822 & 59703 \\
\hline Netherlands (A6) & 6281686 & 5780446 & 672919 & 9835343 & 9951 & 84115 \\
\hline Sweden (A7) & 3677843 & 3431972 & 502880 & 5315121 & 1061 & 105297
\end{tabular}

Table A8. Selected Data of Transport Import for the EU by 2013 (US Dollar, Thousand).

\begin{tabular}{ccccccc}
\hline Countries/Criteria & Sea (C1) & Air (C2) & Rail (C3) & Road (C4) & Pipeline (C5) & Electricity (C6) \\
\hline Belgium (A1) & 7791184 & 3954012 & 621383 & 5933674 & 647938 & 286792 \\
\hline Denmark (A2) & 25817703 & 3057889 & 154435 & 3170628 & 112739 & 45414 \\
\hline France (A3) & 10455959 & 16651198 & 1792450 & 15843932 & 326624 & 475331 \\
\hline Greece (A4) & 4154634 & 1341018 & 31999 & 133438 & 3319 & 36911 \\
\hline Luxembourg (A5) & 382389 & 995806 & 245632 & 2132351 & 19916 & 50454 \\
\hline Sweden (A6) & 3508562 & 3697291 & 494734 & 5697611 & 3188 & 114619 \\
\hline
\end{tabular}

Source: ITC, Trade Map.

\section{References}

1. European Environment Agency. Mitigating Climate Change-Greenhouse Gas Emissions. 2016. Available online: https:/ / www.eea.europa.eu/soer-2015/countries-comparison/climate-change-mitigation (accessed on 31 December 2018).

2. World Health Organization. World Health Statistics 2013. 2016. Available online: https://www.who.int/ gho/publications/world_health_statistics/EN_WHS2013_Full.pdf (accessed on 31 December 2018).

3. European Council. 2009. Available online: http://www.europarl.europa.eu/RegData/etudes/note/join/ 2009/416239/IPOL-ITRE_NT(2009)416239_EN.pdf (accessed on 31 December 2018).

4. European Council Directive of Energy Union and Climate. 2015. Available online: https://ec.europa.eu/ commission/priorities/energy-union-and-climate_en (accessed on 31 December 2018).

5. Kokabian, B.; Ghimire, U.; Gude, V.G. Water deionization with renewable energy production in microalgae-microbial desalination process. Renew. Energy 2018, 122, 354-361. [CrossRef]

6. Melamed, M.; Ben-Tal, A.; Golany, B. A multi-period unit commitment problem under a new hybrid uncertainty set for a renewable energy source. Renew. Energy 2018, 118, 909-917. [CrossRef]

7. D'Adamo, I.; Rosa, P. Current state of renewable energies performances in the European Union: A new reference framework. Energy Convers. Manag. 2016, 121, 84-92. [CrossRef] 
8. Magazzino, C. Is per capita energy use stationary? Panel data evidence for the EMU countries. Energy Explor. Exploit. 2016, 34, 440-448. [CrossRef]

9. Casals, L.C.; Martinez-Laserna, E.; García, B.A.; Nieto, N. Sustainability analysis of the electric vehicle use in Europe for $\mathrm{CO}_{2}$ emissions reduction. J. Clean. Prod. 2016, 127, 425-437. [CrossRef]

10. Pacesila, M.; Burcea, S.G.; Colesca, S.E. Analysis of renewable energies in European Union. Renew. Sustain. Energy Rev. 2016, 56, 156-170. [CrossRef]

11. Khanam, T.; Rahman, A.; Mola-Yudego, B.; Pelkonen, P.; Perez, Y.; Pykäläinen, J. Achievable or unbelievable? Expert perceptions of the European Union targets for emissions, renewables and efficiency. Energy Res. Soc. Sci. 2017, 34, 144-153. [CrossRef]

12. Magazzino, C. Is per capita energy use stationary? Time series evidence for the EMU countries. Energy Explor. Exploit. 2017, 35, 24-32. [CrossRef]

13. Nicolini, M.; Tavoni, M. Are renewable energy subsidies effective? Evidence from Europe. Renew. Sustain. Energy Rev. 2017, 74, 412-423. [CrossRef]

14. Gökgöz, F.; Güvercin, M.T. Energy security and renewable energy efficiency in EU. Renew. Sustain. Energy Rev. 2018, 96, 226-239. [CrossRef]

15. Dominković, D.F.; Bačeković, I.; Pedersen, A.S.; Krajačić, G. The future of transportation in sustainable energy systems: Opportunities and barriers in a clean energy transition. Renew. Sustain. Energy Rev. 2018, 82, 1823-1838. [CrossRef]

16. Moro, A.; Lonza, L. Electricity carbon intensity in European Member States: Impacts on GHG emissions of electric vehicles. Transp. Res. Part D Transp. Environ. 2018, 64, 5-14. [CrossRef]

17. Carrilero, I.; González, M.; Anseán, D.; Viera, J.C.; Chacón, J.; Pereirinha, P.G. Redesigning European Public Transport: Impact of New Battery Technologies in the Design of Electric Bus Fleets. Transp. Res. Procedia 2018, 33, 195-202. [CrossRef]

18. Biresselioglu, M.E.; Kaplan, M.D.; Yilmaz, B.K. Electric mobility in Europe: A comprehensive review of motivators and barriers in decision making processes. Transp. Res. Part A Policy Pract. 2018, 109, 1-13. [CrossRef]

19. Hasan, U.; Whyte, A.; Al Jassmi, H. Critical review and methodological issues in integrated life-cycle analysis on road networks. J. Clean. Prod. 2018. [CrossRef]

20. Wang, C.; Ghadimi, P.; Lim, M.K.; Tseng, M.L. A literature review of sustainable consumption and production: A comparative analysis in developed and developing economies. J. Clean. Prod. 2018. [CrossRef]

21. Liu, C.; Cai, G.; Ge, W.; Yang, D.; Liu, C.; Sun, Z. Oscillation Analysis and Wide-Area Damping Control of DFIGs for Renewable Energy Power Systems Using Line Modal Potential Energy. IEEE Trans. Power Syst. 2018, 33, 3460-3471. [CrossRef]

22. Amiri, S.; Weinberger, G. Increased cogeneration of renewable electricity through energy cooperation in a Swedish district heating system-A case study. Renew. Energy 2018, 116, 866-877. [CrossRef]

23. Li, L.; Cheng, Z.; Yuan, Z.; Gao, Y. Short-term extreme response and fatigue damage of an integrated offshore renewable energy system. Renew. Energy 2018, 126, 617-629. [CrossRef]

24. Haratian, M.; Tabibi, P.; Sadeghi, M.; Vaseghi, B.; Poustdouz, A. A renewable energy solution for stand-alone power generation: A case study of KhshU Site-Iran. Renew. Energy 2018, 125, 926-935. [CrossRef]

25. Thies, C.; Kieckhäfer, K.; Spengler, T.S.; Sodhi, M.S. Operations research for sustainability assessment of products: A review. Eur. J. Oper. Res. 2018. [CrossRef]

26. Waltho, C.; Elhedhli, S.; Gzara, F. Green supply chain network design: A review focused on policy adoption and emission quantification. Int. J. Prod. Econ. 2018. [CrossRef]

27. Rahman, K.A.; Bak, T.; Atanacio, A.; Ionescu, M.; Liu, R.; Nowotny, J. Towards sustainable energy: photocatalysis of Cr-doped $\mathrm{TiO}$ 2. 5. Effect of segregation on surface versus bulk composition. Ionics 2018, 24, 1211-1219. [CrossRef]

28. Mardani, A.; Streimikiene, D.; Cavallaro, F.; Loganathan, N.; Khoshnoudi, M. Carbon dioxide $\left(\mathrm{CO}_{2}\right)$ emissions and economic growth: A systematic review of two decades of research from 1995 to 2017. Sci. Total Environ. 2018. [CrossRef] [PubMed]

29. Oh, T.H.; Hasanuzzaman, M.; Selvaraj, J.; Teo, S.C.; Chua, S.C. Energy policy and alternative energy in Malaysia: Issues and challenges for sustainable growth-An update. Renew. Sustain. Energy Rev. 2018, 81, 3021-3031. [CrossRef] 
30. Steg, L.; Shwom, R.; Dietz, T. What Drives Energy Consumers?: Engaging People in a Sustainable Energy Transition. IEEE Power Energy Mag. 2018, 16, 20-28. [CrossRef]

31. Saavedra, M.M.R.; Fontes, C.H.D.O.; Freires, F.G.M. Sustainable and renewable energy supply chain: A system dynamics overview. Renew. Sustain. Energy Rev. 2018, 82, 247-259.

32. Hatefi, S.M.; Torabi, S.A. A slack analysis framework for improving composite indicators with applications to human development and sustainable energy indices. Econ. Rev. 2018, 37, 247-259. [CrossRef]

33. Perlaviciute, G.; Schuitema, G.; Devine-Wright, P.; Ram, B. At the Heart of a Sustainable Energy Transition: The Public Acceptability of Energy Projects. IEEE Power Energy Mag. 2018, 16, 49-55. [CrossRef]

34. Segura, E.; Morales, R.; Somolinos, J.A. A strategic analysis of tidal current energy conversion systems in the European Union. Appl. Energy 2018, 212, 527-551. [CrossRef]

35. Gerres, T.; Chaves Ávila, J.P.; Linares Llamas, P.; Gómez San Román, T. A review of cross-sector decarbonisation potentials in the European energy intensive industry. J. Clean. Prod. 2018. [CrossRef]

36. García-Álvarez, M.T.; Cabeza-García, L.; Soares, I. Assessment of energy policies to promote photovoltaic generation in the European Union. Energy 2018, 151, 864-874. [CrossRef]

37. Hadjimichael, M. A call for a blue degrowth: Unravelling the European Union's fisheries and maritime policies. Mar. Policy 2018, 94, 158-164. [CrossRef]

38. Child, M.; Bogdanov, D.; Breyer, C. The role of storage technologies for the transition to a $100 \%$ renewable energy system in Europe. Energy Procedia 2018, 155, 44-60. [CrossRef]

39. Tseng, M.L.; Islam, M.S.; Karia, N.; Fauzi, F.A.; Afrin, S. A literature review on green supply chain management: Trends and future challenges. Resour. Conserv. Recycl. 2019, 141, 145-162. [CrossRef]

40. Matschoss, P.; Bayer, B.; Thomas, H.; Marian, A. The German incentive regulation and its practical impact on the grid integration of renewable energy systems. Renew. Energy 2019, 134, 727-738. [CrossRef]

41. Bhardwaj, A.; Joshi, M.; Khosla, R.; Dubash, N.K. More priorities, more problems? Decision-making with multiple energy, development and climate objectives. Energy Res. Soc. Sci. 2019, 49, 143-157. [CrossRef]

42. Savvidis, G.; Siala, K.; Weissbart, C.; Schmidt, L.; Borggrefe, F.; Kumar, S.; Pittel, K.; Madlener, R.; Hufendiek, K. The gap between energy policy challenges and model capabilities. Energy Policy 2019, 125, 503-520. [CrossRef]

43. Zappa, W.; Junginger, M.; van den Broek, M. Is a 100\% renewable European power system feasible by 2050 ? Appl. Energy 2019, 233, 1027-1050. [CrossRef]

44. Verma, O.P.; Manik, G.; Sethi, S.K. A comprehensive review of renewable energy source on energy optimization of black liquor in MSE using steady and dynamic state modeling, simulation and control. Renew. Sustain. Energy Rev. 2019, 100, 90-109. [CrossRef]

45. Dinçer, H.; Hacioglu, U.; Yuksel, S. Balanced scorecard-based performance assessment of Turkish banking sector with analytic network process. Int. J. Decis. Sci. Appl. 2016, 1, 1-21.

46. Dinçer, H.; Yüksel, S. Financial Sector-Based Analysis of the G20 Economies Using the Integrated Decision-Making Approach with DEMATEL and TOPSIS. In Emerging Trends in Banking and Finance; Springer: Cham, Switzerland, 2018; pp. 210-223.

47. Dinçer, H.; Hacıoğlu, Ü.; Yüksel, S. Balanced scorecard-based performance measurement of European airlines using a hybrid multicriteria decision making approach under the fuzzy environment. J. Air Transp. Manag. 2017, 63, 17-33. [CrossRef]

48. Dinçer, H.; Yüksel, S.; Şenel, S. Analyzing the Global Risks for the Financial Crisis after the Great Depression Using Comparative Hybrid Hesitant Fuzzy Decision-Making Models: Policy Recommendations for Sustainable Economic Growth. Sustainability 2018, 10, 3126. [CrossRef]

49. Dinçer, H.; Yuksel, S.; Bozaykut-Buk, T. Evaluation of Financial and Economic Effects on Green Supply Chain Management with Multi-Criteria Decision-Making Approach: Evidence from Companies Listed in BIST. In Handbook of Research on Supply Chain Management for Sustainable Development; IGI Global: Hershey, PA, USA, 2018; pp. 144-175.

50. Dinçer, H.; Yüksel, S.; Çetiner, İ.T. Strategy Selection for Organizational Performance of Turkish Banking Sector with the Integrated Multi-Dimensional Decision-Making Approach. In Handbook of Research on Contemporary Approaches in Management and Organizational Strategy; IGI Global: Hershey, PA, USA, 2019; pp. 273-291. 
51. Dinçer, H.; Yüksel, S.; Martínez, L. Balanced scorecard-based Analysis about European Energy Investment Policies: A hybrid hesitant fuzzy decision-making approach with Quality Function Deployment. Expert Syst. Appl. 2019, 115, 152-171. [CrossRef]

52. Dinçer, H.; Yüksel, S.; Pınarbaşı, F. SERVQUAL-Based Evaluation of Service Quality of Energy Companies in Turkey: Strategic Policies for Sustainable Economic Development. In The Circular Economy and Its Implications on Sustainability and the Green Supply Chain; IGI Global: Hershey, PA, USA, 2019; pp. 142-167.

53. Dinçer, H.; Yüksel, S.; Adalı, Z.; Aydın, R. Evaluating the Role of Research and Development and Technology Investments on Economic Development of E7 Countries. In Organizational Transformation and Managing Innovation in the Fourth Industrial Revolution; IGI Global: Hershey, PA, USA, 2019; pp. 245-263.

54. Yüksel, S.; Dinçer, H.; Emir, Ş. Comparing the performance of Turkish deposit banks by using DEMATEL, Grey Relational Analysis (GRA) and MOORA approaches. World J. Appl. Econ. 2017, 3, 26-47. [CrossRef]

55. Tzeng, G.H.; Chiang, C.H.; Li, C.W. Evaluating intertwined effects in e-learning programs: A novel hybrid MCDM model based on factor analysis and DEMATEL. Expert Syst. Appl. 2007, 32, 1028-1044. [CrossRef]

56. Dinçer, H.; Yüksel, S. Comparative Evaluation of BSC-Based New Service Development Competencies in Turkish Banking Sector with the Integrated Fuzzy Hybrid MCDM Using Content Analysis. Int. J. Fuzzy Syst. 2018, 20, 2497-2516. [CrossRef]

57. Dinçer, H.; Hacıoğlu, Ü. A Comparative Hybrid Method in Technical Analysis for Stock Selection Process in Banking Sector by Fuzzy AHP-Topsis and Vikor Method. In Global Strategies in Banking and Finance; IGI Global: Hershey, PA, USA, 2014; pp. 187-204.

58. Dincer, H. HHI-based evaluation of the European banking sector using an integrated fuzzy approach. Kybernetes 2018. [CrossRef]

59. Baykasoğlu, A.; Gölcük, İ. Development of an interval type-2 fuzzy sets based hierarchical MADM model by combining DEMATEL and TOPSIS. Expert Syst. Appl. 2017, 70, 37-51. [CrossRef]

60. International Trade Center. 2018. Available online: http://www.intracen.org/itc/market-info-tools/ statistics-export-service-country/ (accessed on 31 December 2018).

61. Lee, P.T.W.; Lee, S.W.; Hu, Z.H.; Choi, K.S.; Choi, N.Y.H.; Shin, S.H. Promoting Korean international trade in the East Sea Economic Rim in the context of the Belt and Road Initiative. J. Korea Trade 2018, 22, $212-227$. [CrossRef]

62. Schneider, A. Northern Sea Route: A Strategic Arctic Project of the Russian Federation. Probl. Econ. Transit. 2018, 60, 195-202. [CrossRef]

63. Hilmola, O.P. Unitized Cargo: Growing Truck-Based Volumes at the Sea Ports of Estonia, Sweden and Finland. In The Sulphur Cap in Maritime Supply Chains; Palgrave Pivot: Cham, Switzerland, 2019; pp. 53-72. 